Eskişehir Osmangazi Üniversitesi iiBF Dergisi

Nisan 2020, C. 15, S. 1, 209- 230.

Başvuru : 27.03.2019

Kabul : : 18.01.2020

\title{
K-ortalamalar Kümeleme Analizi İle Belediyelerin Çevre Hizmetlerinin Değerlendirilmesi
}

\author{
Günay Kılıç \\ Ibrahim Budak² \\ Arzu Organ ${ }^{3}$
}

\begin{abstract}
K-ortalamalar Kümeleme Analizi İle Belediyelerin Çevre Hizmetlerinin Değerlendirilmesi

Öz

Halkın yerel ihtiyaçlarını karşılamak üzere kurulan, kuruluş esasları kanunla belirlenen yerel yönetim türlerinden biri de belediyelerdir. Belediyelerin amacı, belediye sorumluluk ve görevleri kapsamındaki hizmetlerini belediye nüfusunun tamamına ulaştırmaktır. Belediyelerin birçok görev ve sorumluluğu bulunmakla birlikte bu çalışmada, Türkiye'deki 81 il belediyesi, çevre hizmetleri açısından değerlendirilmiştir. Bu çalışmada, Türkiye İstatistik Kurumu (TÜIK) tarafından 2001-2016 yılları arasında yayımlanan belediye hizmetleri ile ilgili istatistikler kullanılmıştır. Bu çerçevede, altı adet kriter ele alınmıştır. Kriterlerin ağırlıklarını belirlemek için Çok Kriterli Karar Verme Yöntemlerinden AHP kullanılmıştır. Belirlenen ağırlıklar, ilgili yılların değerleri ile çarpılarak ağırlıklandırılmış bir değer elde edilmiştir. İlgili yılın ağırlıklandırılmış değeri, tek boyutlu kümeleme analizi ile kümelendirilmiştir. illerin yıllar bazında belediye performanslarının değişimi analiz edilmiştir.
\end{abstract}

Using K-means Cluster Analysis for Assessment of Environmental Services of Municipalities

\begin{abstract}
Municipalities are one of the local government types established by law, established to meet the local needs of the people. The purpose of municipalities; to deliver the services of the municipality to the entire municipal population. In this study, although many duties and responsibilities of municipalities in 81 provinces in Turkey is evaluated in terms of municipal environmental services. In this study, statistics on municipal services published between 20012016 by Turkish Statistical Institute (TUIK) were used. In this context, six criteria are discussed. One of the Multi Criteria Decision Methods, AHP was used to determine the weight of the criteria. The weighted weights are multiplied by the values of the relevant years and a weighted value is obtained. The weighted value of the relevant year was clustered with one-dimensional clustering analysis. The changes in municipal performances of provinces were analyzed.
\end{abstract}

Anahtar Kelimeler: K-ortalamalar, Belediye, Çevre, AHP

Keywords: K-means, Municipality, Environment, AHP

\section{Giriş}

Yerel yönetimler örgütlendikleri her coğrafi alan içinde bu alanı paylaşan insanların yerel düzeyde ihtiyaçlarını gidermek için kurulmuş kuruluşlardır. Ekonomik, kültürel ve toplumsal anlamda birçok görevi bulunan yerel yönetimlerin sağlık, ulaşım, kentsel altyapı, imar, su ve kanalizasyon, temizlik ve katı atık yönetimi gibi görevler ön plana çıkmaktadır (Güven ve Şimşek, 2018: 126). Türkiye'de yerel yönetimler Büyükşehir Belediyeleri, Belediyeler, il Özel İdaresi ve Köy Yönetiminden oluşur. Belediyelerin diğer yerel yönetim çeşitlerine nazaran daha etkili olmalarının sebebi mevzuatta daha fazla yetki ve sorumluluk verilmesidir (Zengin, 2009: 117118).

\footnotetext{
1 Ögr. Gör. Pamukkale Üniversitesi, Rektörlük, Bilgi İşlem Daire Başkanlığı. gkilic@pau.edu.tr, Yazar ORCID bilgisi: https://orcid.org/0000-0003-2236-7535

2 Dr. Öğrencisi, Pamukkale Üniversitesi, Sosyal Bilimler Enstitüsü. ibrahimbudak04@gmail.com, Yazar ORCID bilgisi: https://orcid.org/0000-0001-7762-6114

3 Doç. Dr. Pamukkale Üniversitesi, IïBF, İşletme Bölümü. aorgan@pau.edu.tr, Yazar ORCID bilgisi: https://orcid.org/0000-0002-2400-4343
} 
Belediyelerde ve Büyükşehir Belediyelerinde çevre sağlığının korunması, katı atık toplamak ve imha etmek, su ve kanalizasyon hizmetlerinin sağlanması, sağlıklı ve planlı kentleşmeyi denetlemek gibi görevler çevresel görevler arasında sayılabilir (Zengin, 2009: 119).

Çevresel görevlerin belediyelerce ne oranda gerçekleştirildiğini araştıran bir çalışmada, iç̧me suyu, Arıtma Tesisi, Toplanan Tehlikeli Atık Miktarı, Toplanan Akü Miktarı gibi çevresel hizmetleri temsil eden göstergeler belirlenmiş ve bu göstergeler ile belediyeleri kümelenmiştir (Zülfikar ve Beken 2014: 84). Bu çalışmada, daha önceki yapılan çalışmadan farklı olarak Atık Bertaraf Yöntemine Göre Atık Miktar Bertaraf Edilen Atık Miktarı (\%), Atık Hizmeti Verilen Belediye Nüfusunun Toplam Belediye Nüfusuna Oranı (\%), Atık su Arıtma Tesisi ile Hizmet Verilen Belediye Nüfusunun Toplam Belediye Nüfusuna Oranı(\%) , Kanalizasyon Şebekesi ile Hizmet Verilen Belediye Nüfusunun Toplam Belediye Nüfusuna Oranı (\%), İçme ve Kullanma Suyu Arıtma Tesisi ile Hizmet Verilen Belediye Nüfusunun Toplam Belediye Nüfusuna Oranı (\%) ve İçme ve Kullanma Suyu Şebekesi ile Hizmet Verilen Belediye Nüfusunun Toplam Belediye Nüfusuna Oranı (\%) olmak üzere altı kriter belirlenmiştir.

Türkiye'de bulunan 81 il belediyesine ait veriler Tüik'ten alınmış ve 2001 -2016 yılları arasında illerin durumu değerlendirilmiştir. Belirlenen altı kriterin ağırlıklandırmasında Çok Kriterli Karar Verme Yöntemlerinde sıkça kullanılan yöntemlerden olan Analitik Hiyerarşi Prosesi (AHP) kullanılmıştır. Belediyelerin her bir yıla ait çevrecilik değerleri, olması gereken değerden uzaklıkları ile o kritere ait ağrılıklar çarpılmış, elde edilen değerler toplanarak ağırlıklandırılmış toplam çevrecilik hata değerleri bulunmuştur. İlgili yıllarda, illerin Türkiye sıralamaları bu değere göre belirlenmiştir. Toplam çevrecilik hata değerleri, 2001-2016 yılları arasındaki her bir yıl için kümeleme analizi ile gruplanmıştır. Kümeleme yöntemi olarak, kümeleme problemlerinde sıkça kullanılan 'K-ortalamalar yöntemi' seçilmiştir. K-ortalamalar yönteminde en uygun küme sayısı Elbow yöntemi ile belirlenmiştir. illerin yıllar içinde hangi kümeye ait olduğu ve hangi kümeye geçiş yaptığına bakılmıştır. Küme merkezlerinin yıllara göre değişimi ise çalışmanın diğer bir sonucudur.

\section{Literatür Analizi}

Kümeleme analizi, Elbow Yöntemi ve AHP ile ilgili literatür çalışmalarından bazıları aşağıdaki gibidir.

Cieszynska ve ark. (2012) tarafından yapılan çalışmada, Baltık Denizi'nin güney kıyısında, Gdansk Belediyesinin yer aldığı bölgede 8 yıllık bir izleme programına dayanarak su kalitesi değerlendirilmesi yapılmıştır. Çalışmada, 8 su sahasında 15 farklı bölgedeki yüzey suyu incelenmiştir. Su kalitesinin belirlenmesi için 8 parametre belirlenmiştir. Araştırma sırasında elde edilen geniş veri seti için kümeleme analizi kullanılmıştır. Çalışma, kullanılan parametreler ile arazi kullanımının su kalitesi üzerinde bir etkisi olduğunu göstermektedir (Cieszynskavd., 2012: 2017-2029).

Bholowalia ve Kumar (2014) tarafından yapılan çalışmada, Kümeleme analizi ile yüz binlerce küçük ve uygun maliyetli sensör düğümünden oluşan WSN'nin sensör düğümlerinin sanal alt grupları belirlenmeye çalışıımıştır. Kümeleme analizi yapılırken optimum "K" sayısını belirlemek için Elbow yöntemini kullanılmıştır. Elbow yönteminin "K" sayısını belirlemede etkili ve hızlı olduğu vurgulanmıştır (Bholowalia ve Kumar, 2014: 17-24).

Syakur ve ark. (2018) tarafından yapılan çalışmada, en iyi müşteri kümesinin belirlenmesinde kümeleme analizi ve Elbow yöntemi kullanılmıştır. Mal üretimi, satış analizi ve satış politikası için müşteri profili gruplandırılmıştır. Optimum küme sayısını bulmak için toplam karesel 
hatanın düşük olduğu Elbow yöntemi kullanılmıştır. Bu şekilde "k" sayısı üç olarak belirlenmiştir (Syakur vd., 2018: 1-6).

Nydick ve Hill (1992) tarafından yapılan çalışmada, tedarikçi seçim problemi ele alınmıştır. Bir tedarikçi seçiminde yaygın ve etkili kriterlerden bazıları kalite, fiyat, teslimat ve hizmettir. Bu kriterlerin önem derecelerini belirlemek için Analitik Hiyerarşi Süreci kullanılmıştır. Kriterlerden önem derecesi en yüksek olan kalite iken önem derecesi en düşük olan kriter teslimattır. Ayrıca bu kriterlerin satın alma fonksiyonları için önemli olduğu vurgulanmıştır (Nydick ve Hill, 1992: 31-36).

Mustafa ve Al-Bahar (1991) tarafından yapılan çalışmada, AHP ile proje risk değerlendirmesi yapılmıştır. Bir inşaat projesinin teklif aşamasında proje risklerini analiz etmek ve değerlendirmek müteahhitler için önemlidir. Bu yönüyle AHP, karar vericiye bir problemi mantıklı ve rasyonel bir şekilde formüle etmede yardımcı olmak için esnek, kolay anlaşılır bir yol sağlamaktadır. Bu çalışmada, ele alınan projenin genel olarak düşük riskli bir proje olduğu gösterilmiştir (Mustafa ve Al-Bahar, 1991: 46-52).

Ramanathan (2001) tarafından yapılan çalışmada, çevresel etki değerlendirmesi için AHP kullanılmıştır. Yapılan sosyo-ekonomik değerlendirmede çeşitli uzman görüşlerinden faydalanılmıştır. Çalışmada kullanılan fiyat, konum ve yaş kriteri, AHP yöntemi ile analiz edilerek kriterlerin ağırıkları belirlenmiştir. Önem derecesi en yüksek kriter fiyat iken en düşük kriter yaş olarak belirtilmiştir. Çalışmanın çevre etki değerlendirmesinde AHP yönteminin avantajlı olduğu vurgulanmıştır (Ramanathan, 2001: 27-35). Ayrıca, bu çalışmaların yanı sıra, Belediye Hizmet Kalitesinin değerlendirilmesi, güzergâh seçimi, toplu ulaşım sistemlerinin performansı (Bostancı, 2016: 110-130; Hamurcu ve Eren, 2015: 410-419; Güner, 2017: 33-48) gibi çalışmalar da vardır.

\section{Kümeleme Analizi}

Küme analizi gruplanmamış verileri alır ve bu verileri gruplara koymak için otomatik teknikler kullanır. Kümeleme, denetlenmez ve bir öğrenme seti gerektirmez. Sınıflandırma ile ortak bir metodolojik temeli paylaşır. Başka bir deyişle, sınıflandırma ile ilgili matematiksel modellerin çoğu, küme analizine de uygulanabilir (Olson ve Delen, 2008: 16).

Kümeleme teknikleri, tahmin edilecek bir sınıf olmadığında uygulanır, örnekler doğal gruplara bölünür. Tanımlanan gruplar sınırlı olduğu durumda olabilir; böylece herhangi bir örnek yalnızca bir gruba ait olur. Bununla birlikte bir örnek birkaç gruba düşebilecek şekilde üst üste gelebilir. Bir örnek her bir gruba belli olasılık ile dâhil olduğu durum da olabilir. Kümelemenin hiyerarşik olduğu durumlar da bulunmaktadır. Hiyerarşik kümelerde üst düzeyde gruplama yapılır ve bu grupların her biri daha ileri düzeyde - belki de bireysel örneklere kadar alt kümelere bölünür. Hangi kümeleme yönteminin yapılacağı, genellikle mevcut kümeleme araçları tarafından belirlenir. Sayısal alanlarda kümeler oluşturan, örnekleri ayrık kümelere bölen algoritmalar geliştirilmiştir. Yenilemeli mesafeye dayalı klasik kümeleme tekniği ise, K- ortalamalar kümeleme tekniğidir (Witten vd., 2016: 137).

Kümeleme teknikleri, metin dosyaları ve topluluk tespiti gibi doğada birçok alanda yaygın olarak kullanılmaktadır. Kümeleme, bir kümenin içindeki nesnelerin benzer olması veya farklı kümelerdeki nesnelerin önceden belirlenmiş kriterlere göre farklı gruplara ayrılmasını amaçlayan denetimsiz bir sınıflandırma tekniğidir. Kümeleme algoritmaları, bölümleme yöntemleri, hiyerarşik yöntemler, yoğunluk temelli yöntemler, grid tabanlı yöntemler ve model tabanlı yöntemleri olarak özetlenebilir. Pek çok araştırmacı, farklı türlerde ağırlıklandırma yöntemleriyle Kortalama algoritmalarını genişletmiş ve kullanmıştır (Huang vd., 2014: 293). 


\subsection{K-ortalamalar}

Klasik kümeleme tekniğine, K-ortalamalar denir. Bu teknikte, k sayısı önceden belirlenir. Daha sonra, küme merkezleri olarak rastgele noktalar seçilir. Tüm örnekler, normal öklid uzaklık metriğine göre en yakın küme merkezlerine atanır. Bundan sonra, her kümedeki örneklerin merkezi hesaplanır. Hesaplanan merkezler, kendi kümeleri için yeni merkez değerleri olarak alınır. Son olarak, tüm süreç yeni küme merkezleriyle tekrarlanır. Yineleme, küme merkezlerinin sabitlendiği ve sonsuza dek aynı kalacağı ardışık turlarda her kümeye noktalar atanana kadar devam eder. Bu kümeleme yöntemi basit ve etkilidir. Küme merkezini merkez olarak seçmenin, küme noktalarının her birinden merkeze olan toplam kare mesafesini en aza indirdiğini kanıtlamak kolaydır. Yineleme sabitlendikten sonra, her nokta en yakın küme merkezine atanır. Bu sayede, tüm noktaların içinde bulunduğu küme merkezlerine olan uzaklıklarının toplamı en aza indirilmektedir. Her bir küme için toplam mesafenin az olduğu durumda, bütün kümelerde toplam mesafenin en düşük olduğu kesin değildir. İlk küme merkezi seçimine çok bağımlı olduğu bu durumda farklı küme merkezleri seçilerek toplam hatanın azaltılması sağlanmaya çalışılır. Kortalamalar yönteminde kümeleme işlemini hızlandırmak için kümelenecek düzlemler önceden belirlenirse sistem daha hızlı çalışır ama kümeleme performansı düşer (Witten vd., 2016: 137138).

K-ortalama yönteminde $\mathrm{k}=2$ sayısı ile kümelemeyi başlatarak kümelemeyi önce 2 ye bölerek hiyerarşik bir yapı gibi kullanılabilir. k sayısını tespit etmek için kesin bir yöntem olmamakla birlikte 2 den başlayarak her seferinde bir arttırarak en uygun küme sayısını tespit etmeye çalışan yöntemler de vardır (Witten vd., 2016: 139).

K- ortalama, genel kümeleme için çok popüler bir yöntemdir(Zha vd., 2002: 1057). K-ortalamalar algoritması birçok çalışmada kullanılmıştır. K-ortalamalar yöntemindeki en uygun küme sayısını araştıran bir çalışmada, küme içi ve kümeler arası mesafeler ile küme sayısı belirlenmeye çalışılmıştır. Çalışmada, küme içi uzaklıklar küme merkezleri arasındaki uzaklıklara bölünmüş ve bu bölümün en küçük olduğu durumda kümelemenin en iyi olacağı ifade edilmiştir. Uygun küme sayısı renkli resim bölümlendirilmesine uygulanmıştır (Ray ve Turi, 1999: 137-143).

K-ortalamalar formülasyonu ile Eşitlik (3.1) 'de gösterilen amaç fonksiyonu $f$ minimize edilmeye çalışılır (Tucker vd., 2010: 600).

$$
\begin{aligned}
f=\sum_{j=1}^{k} \sum_{x_{i} \in S_{j}}\left\|x_{i}-c_{j}\right\|^{2} \\
S_{j}=\text { Bir veri noktaları kümesidir. } \\
c_{j}=\text { Bir Sj kümesinin merkezidir. } \\
x_{i}=\text { Bir kümeye ait bir veri noktasını temsil eder. } \\
k=\text { Kullanıcı tarafından önceden belirtilen küme sayısı. }
\end{aligned}
$$

\subsection{Elbow Yöntemi}

Literatürde, K-ortalamalar kümeleme analizinde en uygun k sayısını belirleyen yöntemler önerilmiştir. Bu yöntemlere, Başparmak Kuralı, Elbow Yöntemi, Bilgi Ölçütü Yaklaşımı, Bilgi Teorik Bir Yaklaşım, Silueti Kullanarak k Seçme ve Çapraz Doğrulama örnek olarak verilebilir (Kodinariya ve Makwana, 2013: 91).

Bu çalışmada, en uygun küme sayısını belirlemede seçilen yöntem, en eski yöntemden biri olan Elbow yöntemidir. Yöntem, görsel bir yöntemdir. Şöyle ki, k = 2 ile başlanarak küme sayısı, her adımda 1 yükseltilerek kümeler ve eğitim hatası hesaplanır. $k$ için bir birimlik değişimde 
maliyet çarpıcı bir şekilde düştüğü nokta tespit edilir. Küme sayısı değiştirmeye devam edilir ve bundan sonraki değişimde hata aynı doğrultuda devam eder veya artar ise bulunan bu değer istenen k değeridir (Kodinariya ve Makwana, 2013: 92). Elbow yönteminin küme sayısının 3 olduğu gösterimi Şekil 3'te verilmiştir (Kodinariya ve Makwana, 2013: 92).

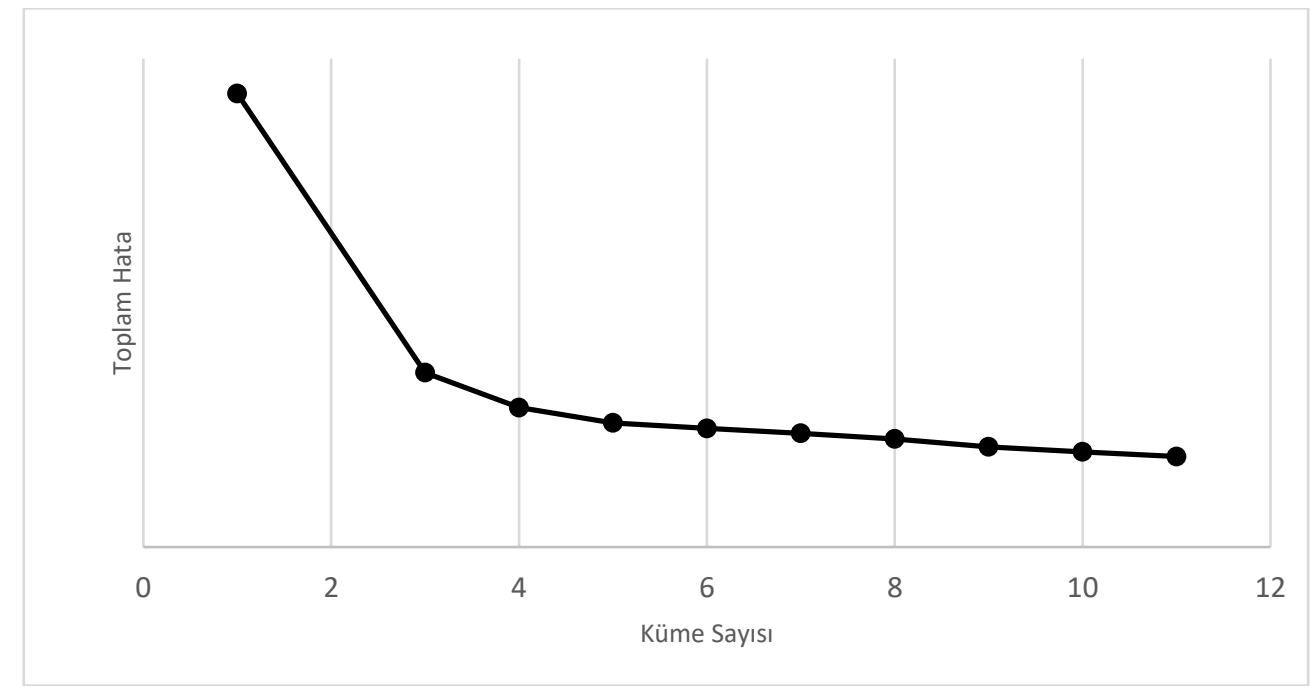

Şekil 1: Elbow Yöntemi ile k Sayısının Belirlenmesi

\section{Analitik Hiyerarşi Süreci}

Analitik Hiyerarşi Süreci (AHP) ikili karşılaştırmalar yoluyla bir ölçüm teorisidir ve kriterleri ağılıklarını belirlemek için uzmanların kararlarına dayanmaktadır. Karşılaştırmalar, bir elemanın verilen öznitelik bakımından diğerine ne kadar baskın olduğunu temsil eden ölçek kullanılarak yapılmaktadır (Saaty, 2008: 83). AHP, Çok Kriterli Karar Verme yöntemlerinden birisidir. Nicel ve nitel performansın ölçümü için sayısal bir ölçekli bir yöntem sunmaktadır. Ölçek, 'en az verilen' değer için 1/9, 'eşit' değer için 1 ve 'kesinlikle daha önemli' değer için 9 değeri arasında değişmektedir. AHP yönteminde uygulanması gereken temel adımlar aşağıdaki gibidir (Vaidya ve Kumar, 2006: 2):

1. Problem belirlemek,

2. Bütün kriterleri, alternatifleri ve sonuçları göz önünde bulundurmak,

3. Çalışmayı etkileyen kriterleri tanımlamak,

4. Problemi, amaç, kriterler, alt kriterler ve alternatifler hiyerarşisine göre yapılandırmak,

5. Her bir elemana karşıılık gelen değerleri sayısal ölçekle belirlemek. Bu, n ( n - 1) / 2 adet karşılaştırma gerekir; burada $n$, unsur sayıdır ve her bir unsur kendisi hariç diğer unsurlar ile kıyaslanmalıdır.

6. Her bir kriter/alternatif için maksimum karşılaştırma değeri, tutarlılık indeksi (CI), tutarlılık oranı (CR) ve normalize edilmiş değerleri bulmak için hesaplamalar yapmak,

7. Maksimum karşılaştırma değeri, $\mathrm{Cl}$ ve $\mathrm{CR}$ yeterliyse, normalize edilmiş değerlere dayalı olarak karar verilir. Aksi halde, bu değerler istenilen aralıkta oluncaya kadar işlemi tekrarlamak. 


\section{Uygulama}

Çalışmanın uygulama kısmı iki alt bölümden oluşmaktadır. Birinci bölümde, belediyelerin çevrecilik performansları ağırlıklandırılmış toplam hata ile değerlendirilmiştir. İkinci bölümde ise belediyeler, birinci bölümde elde edilen hata değerleri kullanılarak tek boyutlu kümeleme analizi ile değerlendirilmiştir.

\subsection{Belediyelerin Çevrecilik Hatalarının Değerlendirilmesi}

Belediyelerin çevresel hizmetlerine göre performanslarının ölçümünü açıklamadan önce bu ölçüm için belirlenen kriterleri açıklamak gerekmektedir. Çalışmada daha önce belirtilen altı kriter şunlardır.

Atığın Bertaraf Edilme Oranı (k1): Belediyede toplanan atıkların bertaraf edilme şekilleri şunlardır: Belediye veya büyükşehir belediye çöplüğünde depolama, başka belediye çöplügünde depolama, açıkta yakma, gömme, düzenli depolama, kompost tesisine gönderilme ve diğer bertaraf işlemleri. Bir belediye toplanan atığın hepsini bertaraf etmelidir. Bertaraf edilen miktar (ton/yıl) toplanan atığa (ton/yıl) bölünerek her bir yıl için yüzdesel değerler elde edilmiştir.

Atık Hizmeti Verilen Belediye Nüfusunun Oranı (k2) : Belediyeler hizmet verdiği belediye nüfusunun tamamına atık toplama hizmeti veremeyebilir. Bu kriterde ilgili yılda yüzdesel olarak belediyelerin hizmet atık hizmeti verdiği nüfusun toplam belediye nüfusa oranı bilgisi vardır.

Atık Su Arıtma Tesisi ile Hizmet Verilen Belediye Nüfusunun Oranı (k3) : Belediyeler hizmet verdiği belediye nüfusunun tamamına atık su arıtma tesisi ile hizmet veremeyebilir. Bu kriterde ilgili yılda belediyelerin atık su arıtma tesisi ile hizmet verdiği nüfusunun toplam belediye nüfusuna oranı bilgisi vardır.

Kanalizasyon Şebekesi ile Hizmet Verilen Belediye Nüfusunun Oranı (k4) : Belediyeler hizmet verdiği belediye nüfusunun tamamına kanalizasyon şebekesi ile hizmet veremeyebilir. Bu kriterde ilgili yılda belediyelerin kanalizasyon şebekesi ile hizmet verdiği nüfusun toplam belediye nüfusuna oranı bilgisi vardır.

İçme Suyu Arıtma Tesisi ile Hizmet Verilen Belediye Nüfusunun Oranı (k5) : Belediyeler hizmet verdiği belediye nüfusunun tamamına içme suyu arıtma tesisi ile hizmet veremeyebilir. Bu kriterde ilgili yılda belediyelerin içme suyu arıtma tesis ile hizmet verdiği nüfusun toplam belediye nüfusuna oranı bilgisi vardır.

İçme ve Kullanma Suyu Şebekesi ile Hizmet Verilen Belediye Nüfusunun Oranı (K6) : Belediyeler hizmet verdiği belediye nüfusun tamamına içme ve kullanma suyu şebekesi ile hizmet veremeyebilir. Bu kriterde ilgili yılda belediyelerin içme ve kullanma suyu şebekesi ile hizmet verdiği nüfusun toplam belediye nüfusa oranı bilgisi vardır.

Çalışmada belirlenen bütün kriterler yüzdesel olarak tutulmaktadır. Bütün kriterler fayda kriteri olduğundan çevre hizmetleri açısından belediyelerin başarılı olması için bu değerlerin 100 ya da 100'e yakın olması beklenmektedir. İstanbul ili 2012 yılında bütün değerlerde 100'ü yakalamış ve çalışmadaki belirlenen kriterlere göre çevrecilik hizmetleri açısından hatasız bir yıl geçirmiş̧ir.

Tablo 1'de TüiK'ten alınan veriler ile oluşturulan 2016 yılı karar matrisi görülmektedir. 2001-2016 yılları arasında tüm illerin çevrecilik değerlerine (TÜiK, 2019) adresinden ulaşılabilir. 
Nisan 2020, C. 15, S. 1

Tablo 1: Tüik Belediye Çevrecilik Matrisi

\begin{tabular}{|c|c|c|c|c|c|c|c|}
\hline iller & YIl & k1 & k2 & k3 & k4 & k5 & k6 \\
\hline Adana & 2016 & 94,13 & 100,00 & 95,00 & 95,00 & 86,00 & 98,00 \\
\hline Adıyaman & 2016 & 100,00 & 98,00 & 60,80 & 96,00 & 1,00 & 100,00 \\
\hline Afyonkarahisar & 2016 & 99,72 & 99,00 & 77,80 & 96,00 & 42,00 & 97,00 \\
\hline Ağrı & 2016 & 100,00 & 100,00 & 0,00 & 86,00 & 58,00 & 94,00 \\
\hline Aksaray & 2016 & 87,67 & 97,00 & 15,10 & 89,00 & 66,00 & 98,00 \\
\hline Amasya & 2016 & 100,00 & 100,00 & 35,20 & 99,00 & 0,00 & 99,00 \\
\hline Ankara & 2016 & 46,73 & 100,00 & 96,00 & 96,00 & 97,00 & 100,00 \\
\hline Antalya & 2016 & 88,18 & 98,00 & 80,00 & 80,00 & 0,00 & 100,00 \\
\hline Ardahan & 2016 & 99,97 & 98,00 & 0,00 & 76,00 & 0,00 & 98,00 \\
\hline Artvin & 2016 & 97,68 & 100,00 & 0,00 & 91,00 & 25,00 & 97,00 \\
\hline Aydın & 2016 & 95,15 & 97,00 & 75,00 & 75,00 & 19,00 & 97,00 \\
\hline Balıkesir & 2016 & 95,05 & 99,00 & 69,90 & 85,00 & 44,00 & 99,00 \\
\hline Bartın & 2016 & 96,07 & 99,00 & 7,80 & 97,00 & 72,00 & 99,00 \\
\hline Batman & 2016 & 98,65 & 97,00 & 84,30 & 95,00 & 4,00 & 97,00 \\
\hline Bayburt & 2016 & 100,00 & 99,00 & 78,90 & 95,00 & 0,00 & 100,00 \\
\hline Bilecik & 2016 & 96,10 & 100,00 & 8,30 & 98,00 & 0,00 & 98,00 \\
\hline Bingöl & 2016 & 99,31 & 98,00 & 63,20 & 96,00 & 0,00 & 97,00 \\
\hline Bitlis & 2016 & 100,00 & 99,00 & 36,20 & 87,00 & 1,00 & 99,00 \\
\hline Bolu & 2016 & 93,17 & 95,00 & 88,20 & 100,00 & 75,00 & 100,00 \\
\hline Burdur & 2016 & 89,55 & 100,00 & 79,20 & 90,00 & 0,00 & 100,00 \\
\hline Bursa & 2016 & 90,83 & 100,00 & 98,00 & 98,00 & 67,00 & 100,00 \\
\hline Çanakkale & 2016 & 92,15 & 100,00 & 84,90 & 96,00 & 46,00 & 99,00 \\
\hline Çankırı & 2016 & 100,00 & 98,00 & 5,70 & 97,00 & 73,00 & 99,00 \\
\hline Çorum & 2016 & 95,03 & 99,00 & 81,70 & 98,00 & 55,00 & 100,00 \\
\hline Denizli & 2016 & 93,79 & 100,00 & 70,00 & 70,00 & 0,00 & 99,00 \\
\hline Diyarbakır & 2016 & 97,68 & 98,00 & 95,00 & 95,00 & 91,00 & 97,00 \\
\hline Düzce & 2016 & 100,00 & 100,00 & 75,00 & 90,00 & 80,00 & 99,00 \\
\hline Edirne & 2016 & 95,84 & 100,00 & 10,00 & 95,00 & 47,00 & 97,00 \\
\hline Elazığ & 2016 & 99,57 & 98,00 & 64,80 & 89,00 & 1,00 & 99,00 \\
\hline Erzincan & 2016 & 100,00 & 100,00 & 2,70 & 93,00 & 0,00 & 100,00 \\
\hline Erzurum & 2016 & 100,00 & 90,00 & 77,30 & 80,00 & 68,00 & 100,00 \\
\hline Eskişehir & 2016 & 93,05 & 99,00 & 98,00 & 98,00 & 78,00 & 100,00 \\
\hline Gaziantep & 2016 & 95,87 & 100,00 & 85,80 & 95,00 & 65,00 & 100,00 \\
\hline Giresun & 2016 & 99,96 & 96,00 & 30,60 & 81,00 & 2,00 & 93,00 \\
\hline Gümüşhane & 2016 & 100,00 & 93,00 & 53,40 & 95,00 & 6,00 & 96,00 \\
\hline Hakkari & 2016 & 100,00 & 99,00 & 0,00 & 25,00 & 0,00 & 91,00 \\
\hline Hatay & 2016 & 98,97 & 99,00 & 31,40 & 75,00 & 1,00 & 97,00 \\
\hline Iğdır & 2016 & 100,00 & 100,00 & 0,00 & 77,00 & 0,00 & 92,00 \\
\hline Isparta & 2016 & 90,44 & 100,00 & 82,00 & 99,00 & 52,00 & 100,00 \\
\hline İstanbul & 2016 & 93,23 & 100,00 & 98,70 & 100,00 & 97,00 & 100,00 \\
\hline İzmir & 2016 & 91,66 & 100,00 & 100,00 & 100,00 & 86,00 & 100,00 \\
\hline Kahramanmaraş & 2016 & 98,93 & 98,00 & 9,00 & 65,00 & 1,00 & 98,00 \\
\hline Karabük & 2016 & 99,38 & 100,00 & 86,90 & 98,00 & 46,00 & 100,00 \\
\hline Karaman & 2016 & 89,82 & 100,00 & 85,40 & 89,00 & 0,00 & 100,00 \\
\hline Kars & 2016 & 100,00 & 100,00 & 11,50 & 90,00 & 43,00 & 97,00 \\
\hline Kastamonu & 2016 & 96,48 & 98,00 & 24,00 & 92,00 & 39,00 & 96,00 \\
\hline Kayseri & 2016 & 97,61 & 99,00 & 86,50 & 94,00 & 0,00 & 99,00 \\
\hline Kırıkkale & 2016 & 100,00 & 100,00 & 78,10 & 98,00 & 91,00 & 100,00 \\
\hline Kırklareli & 2016 & 96,79 & 100,00 & 81,90 & 97,00 & 28,00 & 99,00 \\
\hline Kırşehir & 2016 & 99,34 & 98,00 & 86,70 & 95,00 & 0,00 & 100,00 \\
\hline Kilis & 2016 & 91,17 & 100,00 & 71,40 & 100,00 & 89,00 & 100,00 \\
\hline Kocaeli & 2016 & 91,19 & 100,00 & 99,00 & 99,00 & 93,00 & 100,00 \\
\hline Konya & 2016 & 96,40 & 100,00 & 55,20 & 70,00 & 14,00 & 99,00 \\
\hline Kütahya & 2016 & 98,89 & 100,00 & 66,50 & 97,00 & 19,00 & 100,00 \\
\hline Malatya & 2016 & 96,82 & 98,00 & 73,20 & 88,00 & 0,00 & 100,00 \\
\hline
\end{tabular}


Eskişehir Osmangazi Üniversitesi iiBF Dergisi

\begin{tabular}{lccccccc}
\hline Manisa & 2016 & 95,57 & 99,00 & 26,00 & 87,00 & 39,00 & 96,00 \\
Mardin & 2016 & 94,95 & 89,00 & 1,30 & 80,00 & 0,00 & 76,00 \\
Mersin & 2016 & 93,41 & 99,00 & 73,10 & 82,00 & 69,00 & 99,00 \\
Muğla & 2016 & 90,38 & 99,00 & 77,00 & 77,00 & 38,00 & 100,00 \\
Muş & 2016 & 100,00 & 97,00 & 0,00 & 73,00 & 0,00 & 97,00 \\
Nevşehir & 2016 & 97,43 & 99,00 & 71,90 & 92,00 & 37,00 & 98,00 \\
Niğde & 2016 & 97,43 & 97,00 & 50,60 & 81,00 & 14,00 & 98,00 \\
Ordu & 2016 & 90,85 & 87,00 & 79,00 & 79,00 & 46,00 & 73,00 \\
Osmaniye & 2016 & 99,55 & 96,00 & 50,20 & 77,00 & 0,00 & 96,00 \\
Rize & 2016 & 98,20 & 98,00 & 60,30 & 81,00 & 60,00 & 90,00 \\
Sakarya & 2016 & 91,98 & 99,00 & 49,90 & 60,00 & 63,00 & 100,00 \\
Samsun & 2016 & 72,46 & 83,00 & 77,80 & 78,00 & 86,00 & 95,00 \\
Siirt & 2016 & 99,66 & 99,00 & 64,40 & 96,00 & 54,00 & 98,00 \\
Sinop & 2016 & 88,09 & 96,00 & 0,00 & 98,00 & 30,00 & 100,00 \\
Sivas & 2016 & 97,35 & 100,00 & 74,90 & 98,00 & 50,00 & 100,00 \\
Şanlıurfa & 2016 & 99,59 & 97,00 & 6,90 & 60,00 & 68,00 & 95,00 \\
Şırnak & 2016 & 100,00 & 99,00 & 0,00 & 87,00 & 0,00 & 87,00 \\
Tekirdağ & 2016 & 94,26 & 100,00 & 43,90 & 86,00 & 9,00 & 100,00 \\
Tokat & 2016 & 99,88 & 99,00 & 50,00 & 95,00 & 1,00 & 98,00 \\
Trabzon & 2016 & 93,30 & 100,00 & 59,10 & 80,00 & 69,00 & 85,00 \\
Tunceli & 2016 & 100,00 & 97,00 & 57,50 & 92,00 & 0,00 & 98,00 \\
Uşak & 2016 & 89,30 & 100,00 & 75,70 & 96,00 & 38,00 & 96,00 \\
Van & 2016 & 96,04 & 97,00 & 36,40 & 80,00 & 16,00 & 98,00 \\
Yalova & 2016 & 92,92 & 100,00 & 93,20 & 95,00 & 89,00 & 100,00 \\
Yozgat & 2016 & 99,97 & 99,00 & 45,90 & 95,00 & 6,00 & 100,00 \\
Zonguldak & 2016 & 97,31 & 99,00 & 53,40 & 88,00 & 69,00 & 99,00 \\
\hline Kaynak: TU1K & 200 &
\end{tabular}

Kaynak: TÜiK, https://biruni.tuik.gov.tr/medas/?locale=tr (Erişim Tarihi: 03.01.2019)

Tablo 1 'de boş olan alanlar ' 0 ' değeri yazılarak, analiz için sayısallaştırılmıştır. Veri seti, 2001-2016 yılları arasında benzer 10 adet tablodan oluşmaktadır. 2001-2004 arası her yıl yayınlanan veriler 2004 ten sonra çift yıllarda yayınlanmıştır. Veriye erişim tarihinde 2018 verileri henüz yayınlanmadığından veri setinin en güncel yılı (2016) örnek olarak verilmiştir. Belediyelerin çevresel hizmetlerini ölçebilmek için bu karar matrislerinin yanı sıra, hizmet ölçümünde kullanılan kriterlerin önem dereceleri belirlenmelidir. Bu bağlamda, alanında uzman akademisyenler ile görüşülüp AHP ile kriterlerin önem dereceleri belirlenmiştir. Uzman kişilerin görüşlerinin geometrik ortalamaları alınarak Tablo 2'deki karar matrisi oluşturulmuştur.

Tablo 2: Çevresel Hizmet Kriterleri için AHP Ikili Karşılaştırma Matrisi

\begin{tabular}{ccccccc}
\hline Kriter & k1 & k2 & k3 & k4 & k5 & k6 \\
\hline \hline k1 & 1,00 & 0,33 & 1,00 & 2,08 & 0,30 & 0,38 \\
k2 & 3,00 & 1,00 & 1,26 & 1,59 & 0,63 & 0,63 \\
k3 & 1,00 & 0,79 & 1,00 & 1,44 & 0,79 & 0,79 \\
k4 & 0,48 & 0,63 & 0,69 & 1,00 & 0,55 & 0,79 \\
k5 & 3,30 & 1,59 & 1,26 & 1,82 & 1,00 & 2,00 \\
k6 & 2,62 & 1,59 & 1,26 & 1,26 & 0,50 & 1,00 \\
\hline
\end{tabular}

Tablo 2'deki verilere göre AHP adımları uygulanmıştır. Uygulanan adımlara göre uzman görüşlerinin tutarlılığı hesaplanmıştır(CR=0,052). Tutarlılık değeri 0,1 den küçük olduğu için verilen cevaplar anlamlıdır. Kriterlerin AHP ile belirlenen ağırlıkları Tablo 3'te verilmiştir. 
Tablo 3: Kriterlerin AHP ile Belirlenen Ağırlıkları

\begin{tabular}{cccccc}
\hline k1 & k2 & k3 & k4 & k5 & k6 \\
\hline \hline 0,112189 & 0,179734 & 0,147481 & 0,108632 & 0,261931 & 0,190034 \\
\hline
\end{tabular}

Tablo 3 incelendiğinde $k 5$ kriterinin diğerlerine göre daha önemli olduğu, en az öneme sahip olan kriterin ise k4 olduğu görülmektedir. Kriterlerin ağırlıklarının farklı çıkması çevrecilik hizmetleri değerlendirilirken uzman görüşünden yararlanmasına olanak vermiştir. Belirlenen kriter ağırlıkları belediyenin toplam ağırlıklandııılmış hatasını hesaplamak için kullanılmıştır. Belediyelerin Tablo 1 deki ölçümlerin referans değerden (100) uzaklıkları bir hata değeri olarak kabul edilmiştir. Bu hata değerleri kriterlerin ağılıkları ile çarpılarak ağırlıklandırılmış hata değerleri elde edilmiştir. Ağırlıklandırımış hatalar toplanmış her bir il için ilgili yılın toplam hatası hesaplanmış ve sıralamalar bu toplam hata değerine göre yapılmıştır. Tablo 4'te ilgili yıllarda tüm illerin ağırıklandırılmış toplam hataları görülebilir.

Tablo 4: Illerin Yıllara Göre Ağırıklandırılmış Toplam Çevrecilik Hataları

\begin{tabular}{|c|c|c|c|c|c|c|c|c|c|c|}
\hline iller & 2001 & 2002 & 2003 & 2004 & 2006 & 2008 & 2010 & 2012 & 2014 & 2016 \\
\hline Adana & 42,29 & 39,17 & 30,01 & 19,60 & 12,49 & 6,58 & 7,68 & 7,86 & 10,34 & 5,99 \\
\hline Adıyaman & 45,31 & 43,14 & 42,75 & 42,31 & 40,56 & 42,45 & 42,50 & 42,03 & 42,31 & 32,51 \\
\hline Afyonkarahisar & 41,88 & 41,30 & 41,50 & 40,04 & 39,23 & 37,71 & 32,11 & 26,48 & 20,88 & 19,68 \\
\hline Ağrı & 51,11 & 46,97 & 47,23 & 45,93 & 41,02 & 39,34 & 43,46 & 42,31 & 35,27 & 28,41 \\
\hline Aksaray & 40,89 & 38,11 & 43,74 & 41,37 & 29,57 & 34,83 & 38,44 & 31,96 & 25,80 & 24,92 \\
\hline Amasya & 44,49 & 46,34 & 44,70 & 41,56 & 41,45 & 40,40 & 40,81 & 40,96 & 41,09 & 36,05 \\
\hline Ankara & 7,06 & 7,46 & 5,49 & 6,11 & 5,47 & 4,31 & 2,67 & 2,00 & 2,88 & 7,79 \\
\hline Antalya & 45,51 & 44,54 & 43,44 & 43,34 & 41,16 & 39,44 & 36,99 & 31,32 & 31,88 & 33,00 \\
\hline Ardahan & 51,04 & 48,58 & 47,68 & 47,72 & 49,63 & 45,08 & 45,79 & 46,11 & 44,45 & 44,29 \\
\hline Artvin & 47,33 & 46,33 & 42,60 & 40,97 & 35,43 & 33,37 & 34,69 & 34,02 & 32,73 & 36,20 \\
\hline Aydın & 36,27 & 36,82 & 36,58 & 35,03 & 35,24 & 32,38 & 31,42 & 27,38 & 27,58 & 29,27 \\
\hline Balıkesir & 41,50 & 39,64 & 35,25 & 28,31 & 22,93 & 22,21 & 24,21 & 21,48 & 22,31 & 21,66 \\
\hline Bartın & 44,26 & 44,05 & 40,85 & 41,30 & 42,14 & 29,94 & 29,66 & 23,79 & 22,34 & 22,07 \\
\hline Batman & 46,19 & 43,92 & 43,19 & 42,98 & 42,72 & 42,55 & 42,23 & 30,06 & 31,94 & 29,27 \\
\hline Bayburt & 41,46 & 41,65 & 41,35 & 41,43 & 41,05 & 40,69 & 40,60 & 40,55 & 40,01 & 30,03 \\
\hline Bilecik & 41,78 & 41,67 & 41,74 & 41,16 & 40,79 & 40,66 & 41,21 & 41,16 & 41,54 & 40,75 \\
\hline Bingöl & 50,05 & 49,83 & 44,87 & 44,27 & 42,99 & 42,62 & 43,55 & 42,99 & 33,25 & 33,06 \\
\hline Bitlis & 48,37 & 48,50 & 47,59 & 45,55 & 45,78 & 44,04 & 45,33 & 42,77 & 38,28 & 37,12 \\
\hline Bolu & 40,11 & 39,74 & 39,03 & 38,79 & 40,11 & 38,97 & 18,62 & 11,53 & 10,25 & 9,95 \\
\hline Burdur & 44,95 & 43,90 & 42,45 & 42,34 & 42,75 & 42,68 & 40,55 & 37,23 & 31,46 & 31,52 \\
\hline Bursa & 22,18 & 16,89 & 15,06 & 15,18 & 12,13 & 10,73 & 10,52 & 6,81 & 7,07 & 10,19 \\
\hline Çanakkale & 34,70 & 33,98 & 34,33 & 34,75 & 33,48 & 32,52 & 30,99 & 28,77 & 23,14 & 17,88 \\
\hline Çankırı & 46,83 & 45,04 & 44,44 & 44,44 & 42,43 & 40,45 & 40,14 & 22,15 & 25,58 & 21,85 \\
\hline Çorum & 34,19 & 30,00 & 24,93 & 24,82 & 21,92 & 26,40 & 22,34 & 20,99 & 19,73 & 15,44 \\
\hline Denizli & 44,87 & 43,46 & 43,17 & 42,87 & 42,19 & 37,36 & 33,02 & 32,26 & 33,71 & 34,76 \\
\hline Diyarbakır & 45,06 & 30,55 & 27,51 & 18,75 & 20,55 & 19,56 & 14,36 & 14,31 & 8,95 & 4,83 \\
\hline Düzce & 23,09 & 17,68 & 18,98 & 17,05 & 10,61 & 17,54 & 13,22 & 9,80 & 10,21 & 10,20 \\
\hline Edirne & 29,98 & 30,75 & 31,16 & 27,91 & 30,18 & 27,30 & 31,09 & 25,46 & 24,63 & 28,74 \\
\hline Elazığ & 35,00 & 34,19 & 33,61 & 33,58 & 30,74 & 31,59 & 31,56 & 30,51 & 32,48 & 32,92 \\
\hline Erzincan & 38,87 & 38,00 & 37,59 & 37,41 & 36,30 & 35,04 & 33,54 & 32,18 & 31,74 & 41,30 \\
\hline Erzurum & 43,26 & 42,69 & 42,21 & 42,02 & 41,66 & 39,88 & 23,07 & 22,56 & 25,51 & 15,70 \\
\hline Eskişehir & 12,22 & 12,43 & 10,65 & 15,50 & 11,20 & 11,00 & 8,39 & 6,07 & 6,64 & 7,23 \\
\hline Gaziantep & 19,77 & 22,00 & 22,27 & 20,20 & 12,98 & 15,72 & 10,20 & 17,63 & 12,33 & 12,27 \\
\hline Giresun & 51,12 & 50,44 & 49,10 & 50,35 & 48,07 & 48,04 & 41,93 & 41,01 & 39,57 & 40,02 \\
\hline Gümüşhane & 45,08 & 43,89 & 43,81 & 42,88 & 43,67 & 43,85 & 43,44 & 43,36 & 40,25 & 34,06 \\
\hline Hakkari & 55,69 & 52,07 & 51,30 & 49,59 & 52,45 & 49,81 & 53,36 & 51,64 & 51,15 & 50,98 \\
\hline Hatay & 46,28 & 48,33 & 45,55 & 44,61 & 42,16 & 40,89 & 39,74 & 39,29 & 38,93 & 39,63 \\
\hline Iğdır & 45,88 & 43,32 & 39,12 & 38,96 & 39,37 & 40,17 & 46,16 & 47,13 & 48,19 & 44,96 \\
\hline Isparta & 27,40 & 27,57 & 27,19 & 26,60 & 23,08 & 20,91 & 20,44 & 19,85 & 15,49 & 16,41 \\
\hline
\end{tabular}


Eskişehir Osmangazi Üniversitesi iiBF Dergisi

\begin{tabular}{|c|c|c|c|c|c|c|c|c|c|c|}
\hline İstanbul & 10,02 & 8,11 & 8,67 & 5,04 & 3,95 & 4,68 & 5,71 & 0,00 & 0,32 & 1,74 \\
\hline İzmir & 26,40 & 24,33 & 24,20 & 23,64 & 23,13 & 20,93 & 9,59 & 17,14 & 8,52 & 4,60 \\
\hline Kahramanmaraş & 47,49 & 46,50 & 45,19 & 45,37 & 43,84 & 43,72 & 43,45 & 43,05 & 45,15 & 44,01 \\
\hline Karabük & 37,18 & 32,98 & 29,17 & 26,99 & 28,02 & 25,43 & 24,34 & 14,16 & 21,08 & 16,36 \\
\hline Karaman & 42,62 & 40,42 & 40,06 & 39,29 & 39,96 & 34,08 & 33,18 & 32,40 & 30,31 & 30,68 \\
\hline Kars & 46,26 & 45,10 & 43,33 & 43,11 & 40,64 & 41,10 & 38,39 & 32,30 & 31,05 & 29,64 \\
\hline Kastamonu & 38,46 & 38,30 & 39,08 & 38,10 & 37,91 & 34,86 & 33,11 & 32,79 & 31,21 & 29,57 \\
\hline Kayseri & 44,72 & 44,07 & 34,10 & 33,53 & 29,41 & 29,88 & 28,46 & 28,09 & 28,79 & 29,47 \\
\hline Kırıkkale & 24,40 & 23,56 & 22,57 & 20,70 & 18,45 & 18,61 & 18,17 & 18,13 & 17,68 & 5,80 \\
\hline Kırklareli & 41,15 & 40,98 & 39,93 & 39,82 & 35,67 & 35,07 & 35,25 & 35,39 & 25,56 & 22,40 \\
\hline Kırşehir & 47,24 & 46,03 & 45,43 & 45,04 & 43,51 & 44,05 & 36,79 & 34,91 & 32,41 & 29,13 \\
\hline Kilis & 43,01 & 42,65 & 41,88 & 41,88 & 42,13 & 26,20 & 16,90 & 18,55 & 6,24 & 8,09 \\
\hline Kocaeli & 21,72 & 22,74 & 22,71 & 6,37 & 12,94 & 3,56 & 4,13 & 3,02 & 2,35 & 3,08 \\
\hline Konya & 42,01 & 39,76 & 38,68 & 38,85 & 39,50 & 37,31 & 30,66 & 25,98 & 29,41 & 32,99 \\
\hline Kütahya & 34,37 & 33,32 & 32,71 & 32,65 & 31,63 & 30,37 & 28,98 & 29,32 & 27,13 & 26,61 \\
\hline Malatya & 44,72 & 43,97 & 43,30 & 34,46 & 31,19 & 31,40 & 31,35 & 31,22 & 35,20 & 32,17 \\
\hline Manisa & 36,81 & 37,44 & 36,71 & 37,56 & 35,19 & 31,74 & 30,31 & 28,75 & 37,12 & 29,74 \\
\hline Mardin & 49,67 & 45,93 & 47,30 & 46,38 & 45,80 & 44,71 & 43,73 & 42,90 & 47,09 & 50,03 \\
\hline Mersin & 30,37 & 31,34 & 31,46 & 29,13 & 25,13 & 20,44 & 20,09 & 15,53 & 16,12 & 15,15 \\
\hline Muğla & 44,90 & 43,35 & 41,44 & 38,08 & 38,10 & 37,77 & 36,23 & 31,37 & 30,89 & 23,39 \\
\hline Muş & 56,40 & 52,93 & 52,85 & 52,83 & 50,64 & 49,22 & 49,33 & 47,01 & 45,35 & 44,98 \\
\hline Nevşehir & 42,91 & 42,12 & 41,92 & 41,50 & 40,47 & 39,11 & 34,23 & 26,51 & 22,40 & 22,36 \\
\hline Niğde & 44,65 & 43,45 & 43,35 & 44,97 & 38,38 & 37,46 & 39,88 & 36,79 & 37,85 & 33,08 \\
\hline Ordu & 52,40 & 50,94 & 48,69 & 45,30 & 37,58 & 42,19 & 40,92 & 36,48 & 34,34 & 28,02 \\
\hline Osmaniye & 47,42 & 45,50 & 39,46 & 39,08 & 37,56 & 35,90 & 35,35 & 35,83 & 37,01 & 37,57 \\
\hline Rize & 55,55 & 43,76 & 43,39 & 38,23 & 30,06 & 28,80 & 27,97 & 27,53 & 27,11 & 20,86 \\
\hline Sakarya & 32,52 & 31,70 & 27,66 & 17,69 & 16,90 & 10,01 & 12,28 & 18,89 & 18,58 & 22,50 \\
\hline Samsun & 28,32 & 28,61 & 27,21 & 24,93 & 23,72 & 26,30 & 23,77 & 22,50 & 27,63 & 16,43 \\
\hline Siirt & 43,33 & 43,35 & 43,20 & 41,91 & 42,56 & 41,83 & 36,24 & 29,01 & 11,41 & 18,33 \\
\hline Sinop & 42,02 & 40,32 & 40,50 & 40,49 & 40,53 & 39,88 & 43,04 & 42,03 & 33,10 & 35,36 \\
\hline Sivas & 43,83 & 43,06 & 42,75 & 42,20 & 42,41 & 32,38 & 21,18 & 18,82 & 17,47 & 17,31 \\
\hline Şanlıurfa & 38,68 & 37,20 & 27,05 & 25,70 & 28,40 & 27,22 & 28,12 & 28,17 & 34,29 & 27,99 \\
\hline Şırnak & 51,38 & 50,54 & 49,22 & 45,84 & 43,73 & 44,58 & 44,08 & 44,22 & 43,54 & 45,00 \\
\hline Tekirdağ & 41,57 & 38,55 & 37,84 & 37,24 & 40,60 & 40,78 & 40,71 & 37,61 & 25,67 & 34,27 \\
\hline Tokat & 44,89 & 44,20 & 43,35 & 42,31 & 41,76 & 39,66 & 36,74 & 34,77 & 34,49 & 34,42 \\
\hline Trabzon & 39,95 & 37,72 & 37,87 & 36,03 & 34,23 & 31,36 & 23,94 & 21,50 & 22,67 & 19,93 \\
\hline Tunceli & 43,68 & 42,27 & 43,36 & 42,61 & 42,48 & 42,43 & 42,53 & 42,43 & 34,02 & 34,25 \\
\hline Uşak & 43,35 & 42,57 & 42,53 & 42,35 & 37,89 & 33,79 & 33,95 & 23,62 & 21,12 & 22,22 \\
\hline Van & 42,62 & 42,71 & 42,35 & 39,91 & 39,36 & 32,79 & 40,53 & 38,43 & 37,02 & 34,92 \\
\hline Yalova & 19,45 & 20,05 & 11,53 & 10,20 & 7,17 & 15,18 & 12,47 & 2,08 & 2,40 & 5,22 \\
\hline Yozgat & 46,83 & 44,82 & 43,96 & 44,63 & 40,29 & 41,19 & 39,67 & 37,33 & 35,61 & 33,33 \\
\hline Zonguldak & 28,48 & 31,57 & 27,21 & 24,97 & 23,79 & 25,07 & 25,26 & 23,69 & 21,95 & 16,97 \\
\hline
\end{tabular}

Tablo 4 incelendiğinde belediyelerin çevrecilik performanslarının yıllara göre değişimi görülmektedir. Hatanın değerinin bir önceki yıla göre düşmesi belediyenin bir önceki yıla göre daha iyi çevrecilik değerleri elde ettiği anlamına gelmektedir. Çalışma toplam çevrecilik hatası açısından, Diyarbakır, Adana, Kilis, Rize ve Bolu illerinin 2001 yılından 2016 yılına kadar sayısal anlamda en çok gelişme gösteren ilk 5 il olduğu görülmektedir. Erzincan, Mardin illerinin, 2016 yılındaki verilerinin 2001 yılından daha geride olduğu ortaya çıkmaktadır. Her bir yıla göre kendi arasında sıralandığında illerin ilgili yıllardaki Türkiye sıralamalarının bulunduğu Tablo 5 elde edilir. 
Nisan 2020, C. 15, S. 1

Tablo 5: Illerin Yıllar Içinde Türkiye Sıralaması

\begin{tabular}{|c|c|c|c|c|c|c|c|c|c|c|}
\hline iller & 2001 & 2002 & 2003 & 2004 & 2006 & 2008 & 2010 & 2012 & 2014 & 2016 \\
\hline Adana & 38 & 31 & 19 & 10 & 7 & 4 & 4 & 7 & 12 & 7 \\
\hline Adıyaman & 59 & 48 & 52 & 57 & 51 & 68 & 68 & 68 & 74 & 53 \\
\hline Afyonkarahisar & 35 & 38 & 43 & 43 & 42 & 47 & 38 & 31 & 21 & 25 \\
\hline Ağrı & 75 & 72 & 73 & 76 & 55 & 51 & 73 & 70 & 61 & 40 \\
\hline Aksaray & 29 & 28 & 64 & 48 & 23 & 39 & 54 & 46 & 35 & 36 \\
\hline Amasya & 49 & 70 & 68 & 51 & 58 & 57 & 63 & 65 & 72 & 67 \\
\hline Ankara & 1 & 1 & 1 & 2 & 2 & 2 & 1 & 2 & 4 & 9 \\
\hline Antalya & 60 & 62 & 63 & 65 & 57 & 52 & 52 & 44 & 48 & 56 \\
\hline Ardahan & 74 & 75 & 76 & 78 & 79 & 78 & 78 & 78 & 76 & 76 \\
\hline Artvin & 68 & 69 & 51 & 45 & 33 & 36 & 45 & 52 & 52 & 68 \\
\hline Aydın & 21 & 23 & 27 & 28 & 32 & 33 & 36 & 33 & 38 & 44 \\
\hline Balıkesir & 32 & 32 & 26 & 21 & 14 & 16 & 23 & 21 & 25 & 28 \\
\hline Bartın & 48 & 59 & 40 & 47 & 62 & 26 & 30 & 28 & 26 & 30 \\
\hline Batman & 62 & 57 & 55 & 63 & 69 & 69 & 67 & 41 & 49 & 43 \\
\hline Bayburt & 31 & 39 & 41 & 49 & 56 & 60 & 61 & 64 & 70 & 49 \\
\hline Bilecik & 34 & 40 & 44 & 46 & 54 & 59 & 65 & 67 & 73 & 73 \\
\hline Bingöl & 73 & 76 & 69 & 66 & 71 & 70 & 74 & 74 & 54 & 57 \\
\hline Bitlis & 71 & 74 & 75 & 74 & 76 & 74 & 77 & 72 & 67 & 69 \\
\hline Bolu & 28 & 33 & 33 & 36 & 47 & 49 & 15 & 9 & 11 & 11 \\
\hline Burdur & 56 & 56 & 49 & 58 & 70 & 71 & 60 & 59 & 46 & 51 \\
\hline Bursa & 7 & 4 & 5 & 5 & 6 & 6 & 8 & 6 & 7 & 12 \\
\hline Çanakkale & 19 & 21 & 25 & 27 & 29 & 34 & 33 & 38 & 29 & 23 \\
\hline Çankırı & 65 & 64 & 67 & 67 & 66 & 58 & 58 & 23 & 33 & 29 \\
\hline Çorum & 17 & 13 & 11 & 14 & 13 & 21 & 19 & 20 & 20 & 16 \\
\hline Denizli & 53 & 53 & 54 & 61 & 64 & 45 & 39 & 48 & 55 & 64 \\
\hline Diyarbakır & 57 & 14 & 16 & 9 & 12 & 12 & 12 & 11 & 9 & 4 \\
\hline Düzce & 8 & 5 & 6 & 7 & 4 & 10 & 11 & 8 & 10 & 13 \\
\hline Edirne & 14 & 15 & 20 & 20 & 25 & 23 & 34 & 29 & 30 & 41 \\
\hline Elazığ & 20 & 22 & 23 & 25 & 26 & 30 & 37 & 42 & 51 & 54 \\
\hline Erzincan & 26 & 27 & 29 & 31 & 35 & 41 & 42 & 47 & 47 & 74 \\
\hline Erzurum & 43 & 45 & 47 & 54 & 59 & 54 & 20 & 25 & 31 & 17 \\
\hline Eskişehir & 3 & 3 & 3 & 6 & 5 & 7 & 5 & 5 & 6 & 8 \\
\hline Gaziantep & 5 & 7 & 7 & 11 & 9 & 9 & 7 & 14 & 14 & 14 \\
\hline Giresun & 76 & 77 & 78 & 80 & 78 & 79 & 66 & 66 & 69 & 72 \\
\hline Gümüşhane & 58 & 55 & 65 & 62 & 73 & 73 & 71 & 76 & 71 & 60 \\
\hline Hakkari & 80 & 80 & 80 & 79 & 81 & 81 & 81 & 81 & 81 & 81 \\
\hline Hatay & 64 & 73 & 72 & 68 & 63 & 62 & 56 & 63 & 68 & 71 \\
\hline Iğdır & 61 & 49 & 35 & 38 & 44 & 56 & 79 & 80 & 80 & 77 \\
\hline Isparta & 11 & 11 & 13 & 18 & 15 & 14 & 17 & 19 & 15 & 19 \\
\hline İstanbul & 2 & 2 & 2 & 1 & 1 & 3 & 3 & 1 & 1 & 1 \\
\hline İzmir & 10 & 10 & 10 & 13 & 16 & 15 & 6 & 13 & 8 & 3 \\
\hline Kahramanmaraş & 70 & 71 & 70 & 73 & 75 & 72 & 72 & 75 & 77 & 75 \\
\hline Karabük & 23 & 19 & 18 & 19 & 20 & 18 & 24 & 10 & 22 & 18 \\
\hline Karaman & 39 & 36 & 38 & 40 & 46 & 38 & 41 & 50 & 42 & 50 \\
\hline Kars & 63 & 65 & 58 & 64 & 53 & 63 & 53 & 49 & 44 & 47 \\
\hline Kastamonu & 24 & 29 & 34 & 34 & 39 & 40 & 40 & 51 & 45 & 46 \\
\hline Kayseri & 52 & 60 & 24 & 24 & 22 & 25 & 28 & 35 & 40 & 45 \\
\hline Kırıkkale & 9 & 9 & 8 & 12 & 11 & 11 & 14 & 15 & 18 & 6 \\
\hline Kırklareli & 30 & 37 & 37 & 41 & 34 & 42 & 46 & 55 & 32 & 33 \\
\hline Kırşehir & 67 & 68 & 71 & 71 & 72 & 75 & 51 & 54 & 50 & 42 \\
\hline Kilis & 42 & 44 & 45 & 52 & 61 & 19 & 13 & 16 & 5 & 10 \\
\hline Kocaeli & 6 & 8 & 9 & 3 & 8 & 1 & 2 & 4 & 2 & 2 \\
\hline Konya & 36 & 34 & 32 & 37 & 45 & 44 & 32 & 30 & 41 & 55 \\
\hline Kütahya & 18 & 20 & 22 & 23 & 28 & 27 & 29 & 40 & 37 & 37 \\
\hline Malatya & 51 & 58 & 57 & 26 & 27 & 29 & 35 & 43 & 60 & 52 \\
\hline
\end{tabular}




\begin{tabular}{|c|c|c|c|c|c|c|c|c|c|c|}
\hline Manisa & 22 & 25 & 28 & 32 & 31 & 31 & 31 & 37 & 65 & 48 \\
\hline Mardin & 72 & 67 & 74 & 77 & 77 & 77 & 75 & 73 & 79 & 80 \\
\hline Mersin & 15 & 16 & 21 & 22 & 19 & 13 & 16 & 12 & 16 & 15 \\
\hline Muğla & 55 & 51 & 42 & 33 & 40 & 48 & 48 & 45 & 43 & 35 \\
\hline Muş & 81 & 81 & 81 & 81 & 80 & 80 & 80 & 79 & 78 & 78 \\
\hline Nevşehir & 41 & 41 & 46 & 50 & 49 & 50 & 44 & 32 & 27 & 32 \\
\hline Niğde & 50 & 52 & 60 & 70 & 41 & 46 & 57 & 58 & 66 & 58 \\
\hline Ordu & 78 & 79 & 77 & 72 & 37 & 66 & 64 & 57 & 58 & 39 \\
\hline Osmaniye & 69 & 66 & 36 & 39 & 36 & 43 & 47 & 56 & 63 & 70 \\
\hline Rize & 79 & 54 & 62 & 35 & 24 & 24 & 26 & 34 & 36 & 27 \\
\hline Sakarya & 16 & 18 & 17 & 8 & 10 & 5 & 9 & 18 & 19 & 34 \\
\hline Samsun & 12 & 12 & 15 & 15 & 17 & 20 & 21 & 24 & 39 & 20 \\
\hline Siirt & 44 & 50 & 56 & 53 & 68 & 65 & 49 & 39 & 13 & 24 \\
\hline Sinop & 37 & 35 & 39 & 44 & 50 & 55 & 70 & 68 & 53 & 66 \\
\hline Sivas & 47 & 47 & 53 & 55 & 65 & 32 & 18 & 17 & 17 & 22 \\
\hline Şanlıurfa & 25 & 24 & 12 & 17 & 21 & 22 & 27 & 36 & 57 & 38 \\
\hline Şırnak & 77 & 78 & 79 & 75 & 74 & 76 & 76 & 77 & 75 & 79 \\
\hline Tekirdağ & 33 & 30 & 30 & 30 & 52 & 61 & 62 & 61 & 34 & 62 \\
\hline Tokat & 54 & 61 & 59 & 56 & 60 & 53 & 50 & 53 & 59 & 63 \\
\hline Trabzon & 27 & 26 & 31 & 29 & 30 & 28 & 22 & 22 & 28 & 26 \\
\hline Tunceli & 46 & 42 & 61 & 60 & 67 & 67 & 69 & 71 & 56 & 61 \\
\hline Uşak & 45 & 43 & 50 & 59 & 38 & 37 & 43 & 26 & 23 & 31 \\
\hline Van & 40 & 46 & 48 & 42 & 43 & 35 & 59 & 62 & 64 & 65 \\
\hline Yalova & 4 & 6 & 4 & 4 & 3 & 8 & 10 & 3 & 3 & 5 \\
\hline Yozgat & 66 & 63 & 66 & 69 & 48 & 64 & 55 & 60 & 62 & 59 \\
\hline Zonguldak & 13 & 17 & 14 & 16 & 18 & 17 & 25 & 27 & 24 & 21 \\
\hline
\end{tabular}

Tablo 5'te bütün yıllardaki sıralamalar bir arada değerlendirildiğinde; İstanbul, Ankara, Kocaeli, Yalova, Eskişehir en iyi beş il olarak görülmektedir. Hakkâri, Muş, Ardahan, Şırnak, Mardin son 5 sırdaki iller olarak göze çarpmaktadır. Tablo 5 yardımı ile Türkiye'de 2001 - 2016 yılları arasındaki il belediyelerin çevrecilik performansına bakılabilir. il bazında yıllar içinde artışlar ve düşüşler gözlenmiştir. Türkiye'de belediyelerin çevrecilik verileri bir arada değerlendirildiğinde yıllara göre ortalamalarının toplam çevrecilik hatalarının düştüğü tespit edilmiştir. Yıllara göre değişim Şekil 2' de verilmiştir.

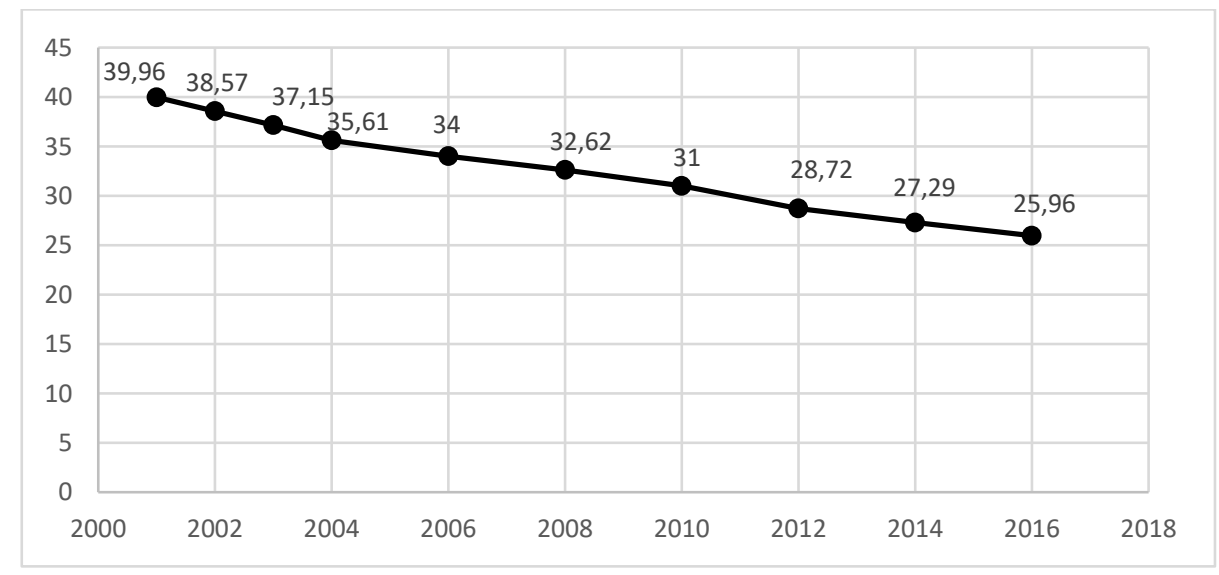

Şekil 2: Ortalama Toplam Hatanın Yıllara Göre Değişimi

Şekil 2 incelendiğinde, Türkiye genelinde belediye çevre hizmetlerinin yıllar geçtikçe bir önceki yıla göre daha iyiye gitmiştir. Bir önceki veri noktasına göre en yüksek gelişme $(\%$ 7,36 ) ile 2012 yılında olmuştur. 


\subsection{Kümeleme Analizi ile Belediyelerin Çevrecilik Hatalarının Değerlendirilmesi}

Kümeleme analizi, benzer verileri gruplamaya yarar. Her bir ilin benzer çevrecilik verilerinden oluşan toplam çevrecilik hataları, her yıl için tek boyutlu kümeleme analizi ile kümelenmiştir. Bu sayede, kümeleme analizi performans ölçümü için kullanılmıştır.

Kümeleme analizinde daha önce açıklanan ve kümeleme problemlerinde sıkça kullanılan Kortalamalar algoritması kullanılmıştır. K-ortalamalar kümeleme analizinde kullanılacak olan en uygun ' $\mathrm{k}$ ' sayısını belirlemek için Elbow yöntemi kullanılmıştır. Elbow yöntemi ile her bir yıl içinde toplam çevrecilik hatalarının 5 kümeye bölünmesi gerektiği tespit edilmiştir. Yılların toplam çevrecilik hata değerlerine kümelerin merkezlerinin değişimi Şekil 3’te verilmiştir.

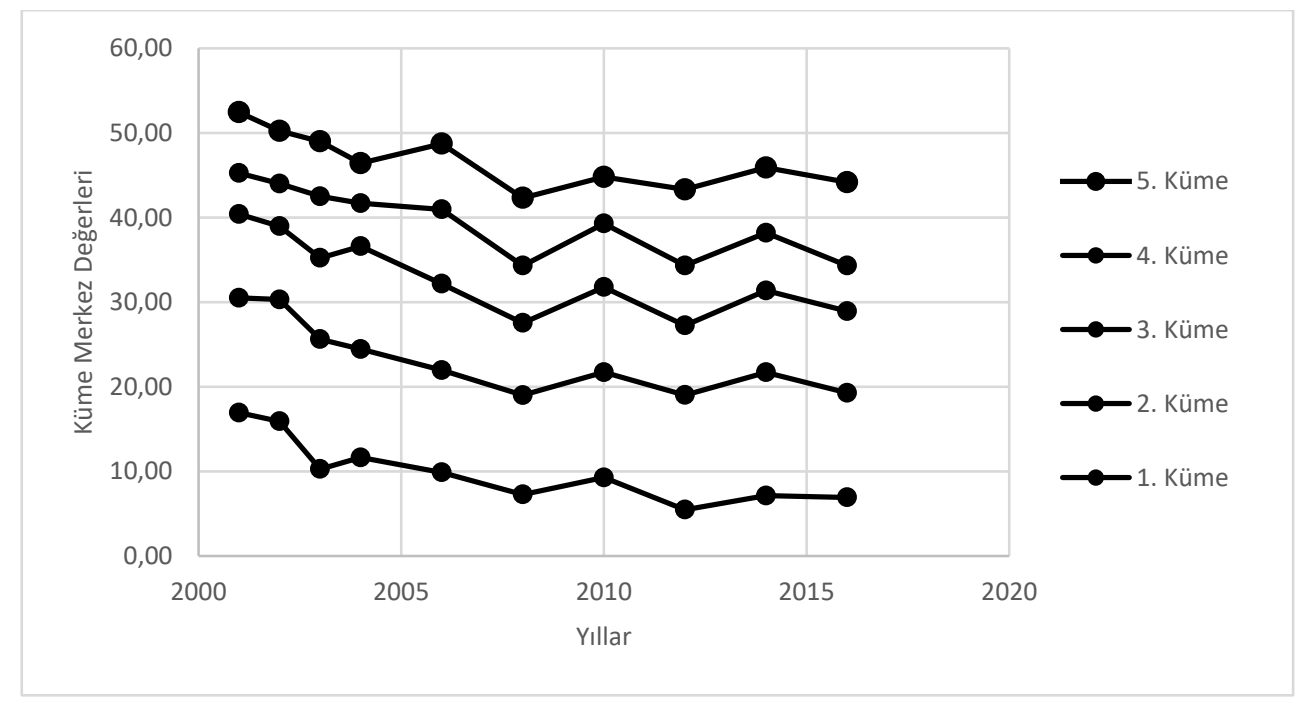

Şekil 3: Küme Merkezlerinin Yıllara Göre Değişimi

Şekil 3 incelendiğinde, ilgili yıllardaki küme merkezleri genelde yıllara göre azalmaktadır. Kümeleme analizi ile çalışılan yıllarda illerin dâhil olduğu kümeler tespit edilmiştir. En iyiden en kötü kümeye doğru sıralaması 1,2,3,4,5 şeklindedir. İllerin o yılda dâhil olduğu kümeler, Tablo 7' de verilmiştir.

Tablo 7: Illerin Yıllara Göre Dâhil Olduğu Kümeler

\begin{tabular}{llcccccccccc}
\hline \multicolumn{1}{c}{ Coğrafi Bölge } & \multicolumn{1}{c}{ iller } & $\mathbf{2 0 0 1}$ & $\mathbf{2 0 0 2}$ & $\mathbf{2 0 0 3}$ & $\mathbf{2 0 0 4}$ & $\mathbf{2 0 0 6}$ & $\mathbf{2 0 0 8}$ & $\mathbf{2 0 1 0}$ & $\mathbf{2 0 1 2}$ & $\mathbf{2 0 1 4}$ & $\mathbf{2 0 1 6}$ \\
\hline \hline Akdeniz & Adana & 3 & 3 & 2 & 2 & 1 & 1 & 1 & 1 & 1 & 1 \\
Güneydoğu Anadolu & Adıyaman & 4 & 4 & 4 & 4 & 4 & 5 & 5 & 5 & 5 & 4 \\
Ege & Afyonkarahisar & 3 & 3 & 4 & 4 & 4 & 4 & 3 & 3 & 2 & 2 \\
Doğu Anadolu & Ağrı & 5 & 4 & 5 & 5 & 4 & 5 & 5 & 5 & 4 & 3 \\
İç Anadolu & Aksaray & 3 & 3 & 4 & 4 & 3 & 4 & 4 & 4 & 2 & 3 \\
Karadeniz & Amasya & 4 & 4 & 4 & 4 & 4 & 5 & 4 & 5 & 4 & 4 \\
İç Anadolu & Ankara & 1 & 1 & 1 & 1 & 1 & 1 & 1 & 1 & 1 & 1 \\
Akdeniz & Antalya & 4 & 4 & 4 & 4 & 4 & 5 & 4 & 4 & 3 & 4 \\
Doğu Anadolu & Ardahan & 5 & 5 & 5 & 5 & 5 & 5 & 5 & 5 & 5 & 5 \\
Karadeniz & Artvin & 4 & 4 & 4 & 4 & 3 & 4 & 3 & 4 & 3 & 4 \\
Ege & Aydın & 3 & 3 & 3 & 3 & 3 & 4 & 3 & 3 & 3 & 3 \\
Marmara & Balıkesir & 3 & 3 & 3 & 2 & 2 & 2 & 2 & 2 & 2 & 2 \\
Karadeniz & Bartın & 4 & 4 & 4 & 4 & 4 & 3 & 3 & 3 & 2 & 2 \\
Güneydoğu Anadolu & Batman & 4 & 4 & 4 & 4 & 4 & 5 & 5 & 3 & 3 & 3 \\
Karadeniz & Bayburt & 3 & 4 & 4 & 4 & 4 & 5 & 4 & 5 & 4 & 3 \\
\hline
\end{tabular}


Eskişehir Osmangazi Üniversitesi iiBF Dergisi

\begin{tabular}{|c|c|c|c|c|c|c|c|c|c|c|c|}
\hline Marmara & Bilecik & 3 & 4 & 4 & 4 & 4 & 5 & 4 & 5 & 4 & 5 \\
\hline Doğu Anadolu & Bingöl & 5 & 5 & 4 & 5 & 4 & 5 & 5 & 5 & 3 & 4 \\
\hline Doğu Anadolu & Bitlis & 4 & 5 & 5 & 5 & 5 & 5 & 5 & 5 & 4 & 4 \\
\hline Karadeniz & Bolu & 3 & 3 & 4 & 3 & 4 & 5 & 2 & 1 & 1 & 1 \\
\hline Akdeniz & Burdur & 4 & 4 & 4 & 4 & 4 & 5 & 4 & 4 & 3 & 3 \\
\hline Marmara & Bursa & 1 & 1 & 1 & 1 & 1 & 1 & 1 & 1 & 1 & 1 \\
\hline Marmara & Çanakkale & 2 & 2 & 3 & 3 & 3 & 4 & 3 & 3 & 2 & 2 \\
\hline İç Anadolu & Çankırı & 4 & 4 & 4 & 5 & 4 & 5 & 4 & 2 & 2 & 2 \\
\hline Karadeniz & Çorum & 2 & 2 & 2 & 2 & 2 & 3 & 2 & 2 & 2 & 2 \\
\hline Ege & Denizli & 4 & 4 & 4 & 4 & 4 & 4 & 3 & 4 & 3 & 4 \\
\hline Güneydoğu Anadolu & Diyarbakır & 4 & 2 & 2 & 2 & 2 & 2 & 1 & 2 & 1 & 1 \\
\hline Karadeniz & Düzce & 1 & 1 & 2 & 1 & 1 & 2 & 1 & 1 & 1 & 1 \\
\hline Marmara & Edirne & 2 & 2 & 3 & 2 & 3 & 3 & 3 & 3 & 2 & 3 \\
\hline Doğu Anadolu & Elazığ & 2 & 2 & 3 & 3 & 3 & 4 & 3 & 3 & 3 & 4 \\
\hline Doğu Anadolu & Erzincan & 3 & 3 & 3 & 3 & 3 & 4 & 3 & 4 & 3 & 5 \\
\hline Doğu Anadolu & Erzurum & 4 & 4 & 4 & 4 & 4 & 5 & 2 & 2 & 2 & 2 \\
\hline İç Anadolu & Eskişehir & 1 & 1 & 1 & 1 & 1 & 1 & 1 & 1 & 1 & 1 \\
\hline Güneydoğu Anadolu & Gaziantep & 1 & 1 & 2 & 2 & 1 & 2 & 1 & 2 & 1 & 1 \\
\hline Karadeniz & Giresun & 5 & 5 & 5 & 5 & 5 & 5 & 4 & 5 & 4 & 5 \\
\hline Karadeniz & Gümüşhane & 4 & 4 & 4 & 4 & 4 & 5 & 5 & 5 & 4 & 4 \\
\hline Doğu Anadolu & Hakkari & 5 & 5 & 5 & 5 & 5 & 5 & 5 & 5 & 5 & 5 \\
\hline Akdeniz & Hatay & 4 & 5 & 4 & 5 & 4 & 5 & 4 & 5 & 4 & 5 \\
\hline Doğu Anadolu & Iğdır & 4 & 4 & 4 & 3 & 4 & 5 & 5 & 5 & 5 & 5 \\
\hline Akdeniz & Isparta & 2 & 2 & 2 & 2 & 2 & 2 & 2 & 2 & 2 & 2 \\
\hline Marmara & İstanbul & 1 & 1 & 1 & 1 & 1 & 1 & 1 & 1 & 1 & 1 \\
\hline Ege & İzmir & 2 & 2 & 2 & 2 & 2 & 2 & 1 & 2 & 1 & 1 \\
\hline Akdeniz & Kahramanmaraş & 4 & 4 & 4 & 5 & 4 & 5 & 5 & 5 & 5 & 5 \\
\hline Karadeniz & Karabük & 3 & 2 & 2 & 2 & 3 & 3 & 2 & 2 & 2 & 2 \\
\hline İç Anadolu & Karaman & 3 & 3 & 4 & 4 & 4 & 4 & 3 & 4 & 3 & 3 \\
\hline Doğu Anadolu & Kars & 4 & 4 & 4 & 4 & 4 & 5 & 4 & 4 & 3 & 3 \\
\hline Karadeniz & Kastamonu & 3 & 3 & 4 & 3 & 4 & 4 & 3 & 4 & 3 & 3 \\
\hline İç Anadolu & Kayseri & 4 & 4 & 3 & 3 & 3 & 3 & 3 & 3 & 3 & 3 \\
\hline İç Anadolu & Kırıkkale & 2 & 2 & 2 & 2 & 2 & 2 & 2 & 2 & 2 & 1 \\
\hline Marmara & Kırklareli & 3 & 3 & 4 & 4 & 3 & 4 & 3 & 4 & 2 & 2 \\
\hline İç Anadolu & Kırşehir & 4 & 4 & 4 & 5 & 4 & 5 & 4 & 4 & 3 & 3 \\
\hline Güneydoğu Anadolu & Kilis & 4 & 4 & 4 & 4 & 4 & 3 & 2 & 2 & 1 & 1 \\
\hline Marmara & Kocaeli & 1 & 1 & 2 & 1 & 1 & 1 & 1 & 1 & 1 & 1 \\
\hline İç Anadolu & Konya & 3 & 3 & 3 & 3 & 4 & 4 & 3 & 3 & 3 & 4 \\
\hline Ege & Kütahya & 2 & 2 & 3 & 3 & 3 & 3 & 3 & 3 & 3 & 3 \\
\hline Doğu Anadolu & Malatya & 4 & 4 & 4 & 3 & 3 & 4 & 3 & 4 & 4 & 4 \\
\hline Ege & Manisa & 3 & 3 & 3 & 3 & 3 & 4 & 3 & 3 & 4 & 3 \\
\hline Güneydoğu Anadolu & Mardin & 5 & 4 & 5 & 5 & 5 & 5 & 5 & 5 & 5 & 5 \\
\hline Akdeniz & Mersin & 2 & 2 & 3 & 2 & 2 & 2 & 2 & 2 & 2 & 2 \\
\hline Ege & Muğla & 4 & 4 & 4 & 3 & 4 & 4 & 4 & 4 & 3 & 2 \\
\hline Doğu Anadolu & Muş & 5 & 5 & 5 & 5 & 5 & 5 & 5 & 5 & 5 & 5 \\
\hline İç Anadolu & Nevşehir & 4 & 4 & 4 & 4 & 4 & 5 & 3 & 3 & 2 & 2 \\
\hline İç Anadolu & Niğde & 4 & 4 & 4 & 5 & 4 & 4 & 4 & 4 & 4 & 4 \\
\hline Karadeniz & Ordu & 5 & 5 & 5 & 5 & 4 & 5 & 4 & 4 & 3 & 3 \\
\hline Akdeniz & Osmaniye & 4 & 4 & 4 & 3 & 4 & 4 & 3 & 4 & 4 & 4 \\
\hline Karadeniz & Rize & 5 & 4 & 4 & 3 & 3 & 3 & 3 & 3 & 3 & 2 \\
\hline Marmara & Sakarya & 2 & 2 & 2 & 1 & 2 & 1 & 1 & 2 & 2 & 2 \\
\hline Karadeniz & Samsun & 2 & 2 & 2 & 2 & 2 & 3 & 2 & 2 & 3 & 2 \\
\hline Güneydoğu Anadolu & Siirt & 4 & 4 & 4 & 4 & 4 & 5 & 4 & 3 & 1 & 2 \\
\hline Karadeniz & Sinop & 3 & 3 & 4 & 4 & 4 & 5 & 5 & 5 & 3 & 4 \\
\hline İç Anadolu & Sivas & 4 & 4 & 4 & 4 & 4 & 4 & 2 & 2 & 2 & 2 \\
\hline Güneydoğu Anadolu & Şanlıurfa & 3 & 3 & 2 & 2 & 3 & 3 & 3 & 3 & 3 & 3 \\
\hline Güneydoğu Anadolu & Şırnak & 5 & 5 & 5 & 5 & 4 & 5 & 5 & 5 & 5 & 5 \\
\hline
\end{tabular}




\begin{tabular}{llllllllllll}
\hline Marmara & Tekirdağ & 3 & 3 & 3 & 3 & 4 & 5 & 4 & 4 & 2 & 4 \\
Karadeniz & Tokat & 4 & 4 & 4 & 4 & 4 & 5 & 4 & 4 & 3 & 4 \\
Karadeniz & Trabzon & 3 & 3 & 3 & 3 & 3 & 4 & 2 & 2 & 2 & 2 \\
Doğu Anadolu & Tunceli & 4 & 4 & 4 & 4 & 4 & 5 & 5 & 5 & 3 & 4 \\
Ege & Uşak & 4 & 4 & 4 & 4 & 4 & 4 & 3 & 3 & 2 & 2 \\
Doğu Anadolu & Van & 3 & 4 & 4 & 4 & 4 & 4 & 4 & 4 & 4 & 4 \\
Marmara & Yalova & 1 & 1 & 1 & 1 & 1 & 2 & 1 & 1 & 1 & 1 \\
İ̧ Anadolu & Yozgat & 4 & 4 & 4 & 5 & 4 & 5 & 4 & 4 & 4 & 4 \\
Karadeniz & Zonguldak & 2 & 2 & 2 & 2 & 2 & 3 & 2 & 3 & 2 & 2 \\
\hline
\end{tabular}

Tablo 7 incelendiğinde, gelişme göstererek daha iyi kümeye geçen veya gerileyerek daha kötü kümeye geçen iller gözlenebilir. Çalışmada, İstanbul, Ankara, Bursa ve Eskişehir her yıl birinci kümede olmayı başarmışlardır. Bu illerden sonra gelen en başarılı beş il ise Kocaeli, Yalova, Düzce, Gaziantep ve Adana'dır. Ardahan, Hakkâri, Muş illeri ise sürekli 5. Kümede yer alarak analiz edilen yıllarda daha iyi bir kümeye geçme başarısı gösterememişlerdir. Bu illeri takip eden Şırnak, Mardin, Giresun, Bitlis, Kahramanmaraş, Hatay, Bingöl ve Ağrı illeri de kümeleme analizi açısından başarısız bulunmuş iller olarak sıralanmaktadır. Coğrafi bölgeler olarak incelendiğinde, Marmara bölgesinin kümeleme analizinde en başarılı bölge olduğu görülmektedir. Marmara bölgesini İç Anadolu, Ege, Karadeniz, Akdeniz, Güneydoğu Anadolu ve Doğu Anadolu bölgeleri takip etmektedir.

Tablo 7'de ağılıklandırılmış toplam çevrecilik hatalarına göre tek boyutlu kümeleme yapılmıştır. Ağırlıklandırılmış çevrecilik hataları toplanmadan altı kriter bir arada değerlendirilerek kümeleme analizi de yapılabilir. Örnek olarak, Tablo 8'de 2016 yılı için ağırlıklandırılmış çevrecilik hata matrisi görülmektedir.

Tablo 8: 2016 Yılı Ağırlıklandırılmış Çevrecilik Hata Matrisi

\begin{tabular}{lccccccc}
\hline \multicolumn{1}{c}{ iller } & Yıl & k1 & k2 & k3 & k4 & k5 & k6 \\
\hline \hline Adana & 2016 & 0,66 & 0,00 & 0,74 & 0,54 & 3,67 & 0,38 \\
Adıyaman & 2016 & 0,00 & 0,36 & 5,78 & 0,43 & 25,93 & 0,00 \\
Afyonkarahisar & 2016 & 0,03 & 0,18 & 3,27 & 0,43 & 15,19 & 0,57 \\
Ağrı & 2016 & 1,38 & 0,54 & 12,52 & 1,19 & 8,91 & 0,38 \\
Aksaray & 2016 & 0,00 & 0,00 & 9,56 & 0,11 & 26,19 & 0,19 \\
Amasya & 2016 & 5,98 & 0,00 & 0,59 & 0,43 & 0,79 & 0,00 \\
Ankara & 2016 & 1,33 & 0,36 & 2,95 & 2,17 & 26,19 & 0,00 \\
Antalya & 2016 & 0,00 & 0,36 & 14,75 & 2,61 & 26,19 & 0,38 \\
Ardahan & 2016 & 0,26 & 0,00 & 14,75 & 0,98 & 19,64 & 0,57 \\
Artvin & 2016 & 0,54 & 0,54 & 3,69 & 2,72 & 21,22 & 0,57 \\
Aydın & 2016 & 0,00 & 0,00 & 14,75 & 1,52 & 11,00 & 1,14 \\
Balıkesir & 2016 & 0,56 & 0,18 & 4,44 & 1,63 & 14,67 & 0,19 \\
Bartın & 2016 & 0,44 & 0,18 & 13,60 & 0,33 & 7,33 & 0,19 \\
Batman & 2016 & 0,15 & 0,54 & 2,32 & 0,54 & 25,15 & 0,57 \\
Bayburt & 2016 & 0,00 & 0,18 & 3,11 & 0,54 & 26,19 & 0,00 \\
Bilecik & 2016 & 0,44 & 0,00 & 13,52 & 0,22 & 26,19 & 0,38 \\
Bingöl & 2016 & 0,08 & 0,36 & 5,43 & 0,43 & 26,19 & 0,57 \\
Bitlis & 2016 & 0,00 & 0,18 & 9,41 & 1,41 & 25,93 & 0,19 \\
Bolu & 2016 & 0,77 & 0,90 & 1,74 & 0,00 & 6,55 & 0,00 \\
Burdur & 2016 & 1,17 & 0,00 & 3,07 & 1,09 & 26,19 & 0,00 \\
Bursa & 2016 & 1,03 & 0,00 & 0,29 & 0,22 & 8,64 & 0,00 \\
Çanakkale & 2016 & 0,70 & 0,00 & 4,42 & 3,26 & 26,19 & 0,19 \\
Çankırı & 2016 & 0,26 & 0,36 & 0,74 & 0,54 & 2,36 & 0,57 \\
Çorum & 2016 & 0,00 & 0,00 & 3,69 & 1,09 & 5,24 & 0,19 \\
Denizli & 2016 & 0,47 & 0,00 & 13,27 & 0,54 & 13,88 & 0,57 \\
Diyarbakır & 2016 & 0,05 & 0,36 & 5,19 & 1,19 & 25,93 & 0,19 \\
Düzce & 2016 & 0,00 & 0,00 & 14,35 & 0,76 & 26,19 & 0,00 \\
\hline & & & & & & &
\end{tabular}


Eskişehir Osmangazi Üniversitesi iiBF Dergisi

\begin{tabular}{|c|c|c|c|c|c|c|c|}
\hline Edirne & 2016 & 0,00 & 1,80 & 3,35 & 2,17 & 8,38 & 0,00 \\
\hline Elazı̆̆ & 2016 & 0,78 & 0,18 & 0,29 & 0,22 & 5,76 & 0,00 \\
\hline Erzincan & 2016 & 0,46 & 0,00 & 2,09 & 0,54 & 9,17 & 0,00 \\
\hline Erzurum & 2016 & 0,00 & 0,72 & 10,24 & 2,06 & 25,67 & 1,33 \\
\hline Eskişehir & 2016 & 0,00 & 1,26 & 6,87 & 0,54 & 24,62 & 0,76 \\
\hline Gaziantep & 2016 & 0,00 & 0,18 & 14,75 & 8,15 & 26,19 & 1,71 \\
\hline Giresun & 2016 & 0,12 & 0,18 & 10,12 & 2,72 & 25,93 & 0,57 \\
\hline Gümüşhane & 2016 & 1,07 & 0,00 & 2,65 & 0,11 & 12,57 & 0,00 \\
\hline Hakkari & 2016 & 0,00 & 0,00 & 14,75 & 2,50 & 26,19 & 1,52 \\
\hline Hatay & 2016 & 0,12 & 0,36 & 13,42 & 3,80 & 25,93 & 0,38 \\
\hline lğdır & 2016 & 0,07 & 0,00 & 1,93 & 0,22 & 14,14 & 0,00 \\
\hline Isparta & 2016 & 1,14 & 0,00 & 2,15 & 1,19 & 26,19 & 0,00 \\
\hline İstanbul & 2016 & 0,00 & 0,00 & 13,05 & 1,09 & 14,93 & 0,57 \\
\hline İzmir & 2016 & 0,40 & 0,36 & 11,21 & 0,87 & 15,98 & 0,76 \\
\hline Kahramanmaraş & 2016 & 0,27 & 0,18 & 1,99 & 0,65 & 26,19 & 0,19 \\
\hline Karabük & 2016 & 0,99 & 0,00 & 4,22 & 0,00 & 2,88 & 0,00 \\
\hline Karaman & 2016 & 0,99 & 0,00 & 0,15 & 0,11 & 1,83 & 0,00 \\
\hline Kars & 2016 & 0,40 & 0,00 & 6,61 & 3,26 & 22,53 & 0,19 \\
\hline Kastamonu & 2016 & 0,12 & 0,00 & 4,94 & 0,33 & 21,22 & 0,00 \\
\hline Kayseri & 2016 & 0,36 & 0,00 & 2,67 & 0,33 & 18,86 & 0,19 \\
\hline Kırıkkale & 2016 & 0,00 & 0,00 & 3,23 & 0,22 & 2,36 & 0,00 \\
\hline Kırklareli & 2016 & 0,07 & 0,36 & 1,96 & 0,54 & 26,19 & 0,00 \\
\hline Kırşehir & 2016 & 0,36 & 0,36 & 3,95 & 1,30 & 26,19 & 0,00 \\
\hline Kilis & 2016 & 0,50 & 0,18 & 10,91 & 1,41 & 15,98 & 0,76 \\
\hline Kocaeli & 2016 & 0,57 & 1,98 & 14,56 & 2,17 & 26,19 & 4,56 \\
\hline Konya & 2016 & 0,74 & 0,18 & 3,97 & 1,96 & 8,12 & 0,19 \\
\hline Kütahya & 2016 & 1,08 & 0,18 & 3,39 & 2,50 & 16,24 & 0,00 \\
\hline Malatya & 2016 & 0,00 & 0,54 & 14,75 & 2,93 & 26,19 & 0,57 \\
\hline Manisa & 2016 & 0,29 & 0,18 & 4,14 & 0,87 & 16,50 & 0,38 \\
\hline Mardin & 2016 & 0,29 & 0,54 & 7,29 & 2,06 & 22,53 & 0,38 \\
\hline Mersin & 2016 & 1,03 & 2,34 & 3,10 & 2,28 & 14,14 & 5,13 \\
\hline Muğla & 2016 & 0,05 & 0,72 & 7,34 & 2,50 & 26,19 & 0,76 \\
\hline Muş & 2016 & 0,20 & 0,36 & 5,85 & 2,06 & 10,48 & 1,90 \\
\hline Nevşehir & 2016 & 0,90 & 0,18 & 7,39 & 4,35 & 9,69 & 0,00 \\
\hline Niğde & 2016 & 3,09 & 3,06 & 3,27 & 2,39 & 3,67 & 0,95 \\
\hline Ordu & 2016 & 0,04 & 0,18 & 5,25 & 0,43 & 12,05 & 0,38 \\
\hline Osmaniye & 2016 & 1,34 & 0,72 & 14,75 & 0,22 & 18,34 & 0,00 \\
\hline Rize & 2016 & 0,30 & 0,00 & 3,70 & 0,22 & 13,10 & 0,00 \\
\hline Sakarya & 2016 & 0,64 & 0,00 & 8,27 & 1,52 & 23,84 & 0,00 \\
\hline Samsun & 2016 & 0,01 & 0,18 & 7,37 & 0,54 & 25,93 & 0,38 \\
\hline Siirt & 2016 & 0,75 & 0,00 & 6,03 & 2,17 & 8,12 & 2,85 \\
\hline Sinop & 2016 & 0,00 & 0,54 & 6,27 & 0,87 & 26,19 & 0,38 \\
\hline Sivas & 2016 & 1,20 & 0,00 & 3,58 & 0,43 & 16,24 & 0,76 \\
\hline Şanlıurfa & 2016 & 0,44 & 0,54 & 9,38 & 2,17 & 22,00 & 0,38 \\
\hline Şırnak & 2016 & 0,79 & 0,00 & 1,00 & 0,54 & 2,88 & 0,00 \\
\hline Tekirdağ & 2016 & 0,00 & 0,18 & 7,98 & 0,54 & 24,62 & 0,00 \\
\hline Tokat & 2016 & 0,30 & 0,18 & 6,87 & 1,30 & 8,12 & 0,19 \\
\hline Trabzon & 2016 & 0,88 & 0,00 & 2,23 & 0,43 & 14,14 & 0,19 \\
\hline Tunceli & 2016 & 0,00 & 0,36 & 13,91 & 0,33 & 7,07 & 0,19 \\
\hline Uşak & 2016 & 0,56 & 0,18 & 2,70 & 0,22 & 11,79 & 0,00 \\
\hline Van & 2016 & 0,76 & 0,00 & 0,19 & 0,00 & 0,79 & 0,00 \\
\hline Yalova & 2016 & 0,94 & 0,00 & 0,00 & 0,00 & 3,67 & 0,00 \\
\hline Yozgat & 2016 & 0,05 & 0,54 & 13,73 & 4,35 & 8,38 & 0,95 \\
\hline Zonguldak & 2016 & 0,00 & 0,18 & 14,75 & 1,41 & 26,19 & 2,47 \\
\hline
\end{tabular}

Çalışmaya konu olan yıllara ait Tablo 8'e benzer 10 adet çevrecilik hata matrisi bulunmaktadır. Her bir yıl kendi içinde kümeleme analizine tabi tutulmuş ve illerin her bir yıldaki 6 kriterin 
birlikte değerlendirildiği kümeleme sonuçları elde edilmiştir Yapılan analizde küme sayısı tek boyutlu kümeleme analizindeki gibi 5 olarak alınmıştır. Kümelemeler sıralanırken, kümelerdeki toplam hataların küme elemanlarına bölümü ile elde edilen ortalama küme puanları kullanılmıştır. Çalışmanın daha önceki kısmına benzer şekilde en iyi küme 1 en kötü 5 olarak alınmıştır. Sonuçlar Tablo 9'da verilmiştir.

Tablo 9: Kriterlerin Birlikte Değerlendirildiğinde illerin Yıllara Göre Dâhil Olduğu Kümeler

\begin{tabular}{|c|c|c|c|c|c|c|c|c|c|c|c|}
\hline Coğrafi Bölge & iller & 2001 & 2002 & 2003 & 2004 & 2006 & 2008 & 2010 & 2012 & 2014 & 2016 \\
\hline Akdeniz & Adana & 3 & 5 & 2 & 1 & 1 & 1 & 1 & 1 & 1 & 1 \\
\hline Güneydoğu Anadolu & Adıyaman & 3 & 5 & 5 & 5 & 5 & 4 & 4 & 4 & 5 & 5 \\
\hline Ege & Afyonkarahisar & 3 & 5 & 5 & 5 & 4 & 3 & 3 & 2 & 2 & 3 \\
\hline Doğu Anadolu & Ağrı & 4 & 5 & 5 & 5 & 5 & 4 & 4 & 4 & 3 & 4 \\
\hline İç Anadolu & Aksaray & 2 & 2 & 4 & 3 & 2 & 2 & 5 & 2 & 3 & 4 \\
\hline Karadeniz & Amasya & 3 & 5 & 5 & 5 & 5 & 4 & 4 & 4 & 5 & 5 \\
\hline İç Anadolu & Ankara & 1 & 1 & 1 & 1 & 1 & 1 & 1 & 1 & 1 & 1 \\
\hline Akdeniz & Antalya & 4 & 4 & 3 & 4 & 4 & 3 & 3 & 3 & 4 & 5 \\
\hline Doğu Anadolu & Ardahan & 4 & 5 & 5 & 5 & 5 & 5 & 5 & 5 & 5 & 5 \\
\hline Karadeniz & Artvin & 3 & 5 & 5 & 5 & 2 & 2 & 4 & 2 & 3 & 4 \\
\hline Ege & Aydın & 2 & 4 & 3 & 4 & 4 & 3 & 3 & 3 & 4 & 3 \\
\hline Marmara & Balıkesir & 3 & 5 & 4 & 3 & 2 & 2 & 1 & 2 & 2 & 3 \\
\hline Karadeniz & Bartın & 3 & 5 & 5 & 5 & 5 & 2 & 1 & 2 & 3 & 4 \\
\hline Güneydoğu Anadolu & Batman & 3 & 5 & 5 & 5 & 5 & 4 & 4 & 3 & 4 & 5 \\
\hline Karadeniz & Bayburt & 3 & 5 & 5 & 5 & 5 & 4 & 4 & 4 & 5 & 5 \\
\hline Marmara & Bilecik & 3 & 5 & 5 & 5 & 5 & 4 & 4 & 4 & 5 & 5 \\
\hline Doğu Anadolu & Bingöl & 5 & 5 & 5 & 5 & 5 & 4 & 4 & 4 & 4 & 5 \\
\hline Doğu Anadolu & Bitlis & 4 & 5 & 5 & 5 & 5 & 4 & 5 & 4 & 5 & 5 \\
\hline Karadeniz & Bolu & 3 & 5 & 5 & 5 & 5 & 4 & 1 & 1 & 1 & 1 \\
\hline Akdeniz & Burdur & 3 & 5 & 5 & 5 & 5 & 4 & 4 & 3 & 4 & 5 \\
\hline Marmara & Bursa & 1 & 1 & 1 & 1 & 1 & 1 & 1 & 1 & 1 & 2 \\
\hline Marmara & Çanakkale & 1 & 3 & 4 & 3 & 2 & 2 & 4 & 2 & 2 & 3 \\
\hline İç Anadolu & Çankırı & 3 & 5 & 5 & 5 & 5 & 4 & 4 & 2 & 3 & 4 \\
\hline Karadeniz & Çorum & 2 & 2 & 2 & 3 & 2 & 3 & 1 & 2 & 2 & 2 \\
\hline Ege & Denizli & 3 & 5 & 5 & 5 & 5 & 3 & 2 & 3 & 4 & 5 \\
\hline Güneydoğu Anadolu & Diyarbakır & 3 & 3 & 2 & 1 & 2 & 2 & 1 & 1 & 1 & 1 \\
\hline Karadeniz & Düzce & 1 & 1 & 1 & 1 & 1 & 1 & 1 & 1 & 1 & 1 \\
\hline Marmara & Edirne & 1 & 3 & 2 & 3 & 2 & 2 & 4 & 2 & 3 & 4 \\
\hline Doğu Anadolu & Elazığ & 2 & 4 & 3 & 2 & 3 & 3 & 2 & 3 & 4 & 5 \\
\hline Doğu Anadolu & Erzincan & 2 & 4 & 3 & 4 & 4 & 3 & 2 & 3 & 4 & 5 \\
\hline Doğu Anadolu & Erzurum & 3 & 5 & 5 & 5 & 5 & 4 & 1 & 2 & 3 & 2 \\
\hline İç Anadolu & Eskişehir & 1 & 1 & 1 & 1 & 1 & 1 & 1 & 1 & 1 & 1 \\
\hline Güneydoğu Anadolu & Gaziantep & 1 & 2 & 3 & 2 & 1 & 1 & 1 & 1 & 1 & 2 \\
\hline Karadeniz & Giresun & 5 & 5 & 5 & 5 & 5 & 5 & 3 & 4 & 5 & 5 \\
\hline Karadeniz & Gümüşhane & 3 & 5 & 5 & 5 & 5 & 4 & 4 & 4 & 5 & 5 \\
\hline Doğu Anadolu & Hakkâri & 5 & 5 & 5 & 5 & 5 & 5 & 5 & 5 & 5 & 5 \\
\hline Akdeniz & Hatay & 4 & 5 & 5 & 4 & 4 & 3 & 3 & 4 & 5 & 5 \\
\hline Doğu Anadolu & Iğdır & 4 & 4 & 3 & 4 & 4 & 3 & 5 & 5 & 5 & 5 \\
\hline Akdeniz & Isparta & 1 & 2 & 2 & 3 & 2 & 2 & 1 & 2 & 2 & 2 \\
\hline Marmara & İstanbul & 1 & 1 & 1 & 1 & 1 & 1 & 1 & 1 & 1 & 1 \\
\hline Ege & İzmir & 2 & 2 & 3 & 2 & 3 & 3 & 1 & 1 & 1 & 1 \\
\hline Akdeniz & Kahramanmaraş & 3 & 5 & 5 & 5 & 5 & 4 & 4 & 4 & 5 & 5 \\
\hline Karadeniz & Karabük & 3 & 4 & 3 & 2 & 3 & 3 & 2 & 1 & 2 & 3 \\
\hline İç Anadolu & Karaman & 2 & 4 & 3 & 4 & 4 & 3 & 2 & 3 & 4 & 5 \\
\hline Doğu Anadolu & Kars & 3 & 5 & 5 & 5 & 5 & 4 & 4 & 2 & 3 & 4 \\
\hline Karadeniz & Kastamonu & 3 & 5 & 4 & 5 & 5 & 2 & 4 & 2 & 3 & 4 \\
\hline İç Anadolu & Kayseri & 3 & 5 & 3 & 2 & 3 & 3 & 2 & 3 & 4 & 5 \\
\hline İç Anadolu & Kırıkkale & 1 & 3 & 2 & 1 & 1 & 1 & 1 & 2 & 3 & 1 \\
\hline
\end{tabular}




\begin{tabular}{|c|c|c|c|c|c|c|c|c|c|c|c|}
\hline Marmara & Kırklareli & 3 & 5 & 5 & 5 & 5 & 4 & 4 & 4 & 2 & 3 \\
\hline İç Anadolu & Kırşehir & 4 & 5 & 5 & 5 & 5 & 5 & 3 & 3 & 4 & 5 \\
\hline Güneydoğu Anadolu & Kilis & 3 & 5 & 5 & 5 & 5 & 2 & 1 & 2 & 1 & 1 \\
\hline Marmara & Kocaeli & 1 & 2 & 2 & 1 & 1 & 1 & 1 & 1 & 1 & 1 \\
\hline İç Anadolu & Konya & 3 & 5 & 4 & 5 & 5 & 4 & 3 & 3 & 4 & 5 \\
\hline Ege & Kütahya & 2 & 4 & 3 & 2 & 3 & 3 & 3 & 3 & 4 & 3 \\
\hline Doğu Anadolu & Malatya & 3 & 5 & 5 & 2 & 3 & 3 & 2 & 3 & 4 & 5 \\
\hline Ege & Manisa & 2 & 4 & 3 & 4 & 4 & 3 & 3 & 2 & 5 & 4 \\
\hline Güneydoğu Anadolu & Mardin & 4 & 5 & 5 & 5 & 5 & 5 & 4 & 4 & 5 & 5 \\
\hline Akdeniz & Mersin & 1 & 3 & 2 & 3 & 2 & 1 & 1 & 1 & 1 & 2 \\
\hline Ege & Muğla & 4 & 4 & 3 & 4 & 4 & 3 & 3 & 3 & 2 & 3 \\
\hline Doğu Anadolu & Muş & 5 & 5 & 5 & 5 & 5 & 5 & 5 & 5 & 5 & 5 \\
\hline İç Anadolu & Nevşehir & 3 & 5 & 5 & 5 & 5 & 4 & 3 & 3 & 2 & 3 \\
\hline İç Anadolu & Niğde & 2 & 4 & 3 & 4 & 4 & 3 & 3 & 3 & 4 & 5 \\
\hline Karadeniz & Ordu & 5 & 5 & 4 & 3 & 2 & 2 & 5 & 2 & 3 & 3 \\
\hline Akdeniz & Osmaniye & 4 & 5 & 3 & 4 & 4 & 3 & 3 & 3 & 4 & 5 \\
\hline Karadeniz & Rize & 5 & 3 & 4 & 3 & 2 & 2 & 1 & 2 & 3 & 2 \\
\hline Marmara & Sakarya & 1 & 3 & 2 & 1 & 2 & 1 & 1 & 1 & 1 & 2 \\
\hline Karadeniz & Samsun & 1 & 3 & 2 & 3 & 2 & 2 & 1 & 2 & 3 & 1 \\
\hline Güneydoğu Anadolu & Siirt & 3 & 5 & 5 & 5 & 5 & 4 & 3 & 3 & 1 & 2 \\
\hline Karadeniz & Sinop & 3 & 5 & 5 & 5 & 5 & 4 & 4 & 4 & 3 & 4 \\
\hline İç Anadolu & Sivas & 3 & 5 & 5 & 5 & 5 & 2 & 1 & 2 & 2 & 2 \\
\hline Güneydoğu Anadolu & Şanlıurfa & 2 & 4 & 2 & 3 & 2 & 2 & 1 & 2 & 3 & 4 \\
\hline Güneydoğu Anadolu & Şırnak & 4 & 5 & 5 & 5 & 5 & 4 & 4 & 4 & 5 & 5 \\
\hline Marmara & Tekirdağ & 3 & 5 & 5 & 5 & 5 & 4 & 4 & 4 & 3 & 5 \\
\hline Karadeniz & Tokat & 3 & 5 & 5 & 5 & 5 & 4 & 3 & 3 & 4 & 5 \\
\hline Karadeniz & Trabzon & 2 & 2 & 4 & 3 & 2 & 2 & 1 & 2 & 3 & 2 \\
\hline Doğu Anadolu & Tunceli & 3 & 5 & 5 & 5 & 5 & 4 & 4 & 4 & 4 & 5 \\
\hline Ege & Uşak & 3 & 5 & 5 & 5 & 4 & 3 & 3 & 3 & 2 & 3 \\
\hline Doğu Anadolu & Van & 2 & 4 & 3 & 4 & 4 & 3 & 3 & 3 & 4 & 5 \\
\hline Marmara & Yalova & 1 & 1 & 1 & 1 & 1 & 1 & 1 & 1 & 1 & 1 \\
\hline İç Anadolu & Yozgat & 3 & 5 & 5 & 5 & 5 & 4 & 4 & 4 & 5 & 5 \\
\hline Karadeniz & Zonguldak & 1 & 3 & 2 & 3 & 2 & 2 & 1 & 2 & 2 & 2 \\
\hline
\end{tabular}

Tablo 9, Tablo 7'ye benzer şekilde illerin yıllara ait kümeleme analizine göre değişimini göstermektedir. Tablo 7'de 6 kriterin çevrecilik hataları toplanmış ve tek boyutlu kümeleme analizi sonuçları verilmiştir. Tablo 9'da ise 6 kriterin birlikte değerlendirildiği çevrecilik hatalarına göre illerin kümeleri görülmektedir.

Tablo 9 ve Tablo 7'de aynı yıllara ait sıralamalara spearman korelasyon testi uygulandığında, yıllara ait korelasyon sonuçları Tablo 10 'da verilmiştir.

Tablo 10: Korelasyon Sonuçları

\begin{tabular}{cccccccccccc}
\hline & $\mathbf{2 0 0 1}$ & $\mathbf{2 0 0 2}$ & $\mathbf{2 0 0 3}$ & $\mathbf{2 0 0 4}$ & $\mathbf{2 0 0 6}$ & $\mathbf{2 0 0 8}$ & $\mathbf{2 0 1 0}$ & $\mathbf{2 0 1 2}$ & $\mathbf{2 0 1 4}$ & $\mathbf{2 0 1 6}$ & Ortalama \\
\hline \hline Korelasyon Sonuçları & 0,90 & 0,83 & 0,85 & 0,83 & 0,89 & 0,86 & 0,87 & 0,89 & 0,92 & 0,90 & 0,87 \\
\hline
\end{tabular}

Tablo 10 incelendiğinde tek boyutlu kümeleme analizi ile çok boyutlu kümeleme analizinin sonuçları arasındaki benzerlik bulunduğu görülmüştür. Bütün yılların kümeleme sıralamaları arasındaki korelasyonların ortalaması 0,87 bulunmuştur. Çok kriterin birlikte değerlendirildiği kümeleme analizi ve tek boyutlu kümeleme analizi arasında pozitif yönde güçlü bir ilişki olduğu söylenebilir.

\section{Sonuç}

Verilen hizmetler açısından kurumları değerlendirmek için Çok Kriterli Karar Verme yöntemlerine ve uzman görüşlerine sıkça başvurulmaktadır. Ayrıca benzer hizmet veren kurumlar belirli özelliklerine göre kümeleme analizi ile gruplanmaktadır. Bu çalışmada, belediyelerin çevresel 
hizmetleri ele alınmış ve çevresel hizmetleri ölçmek için altı kriter belirlenmiştir. Belirlenen altı kriterin AHP ile önem dereceleri belirlenmiştir. Bu önem dereceleri Türkiye'deki 81 il belediyesinin çevrecilik ölçüm değerleri ile birlikte değerlendirilmiştir. Bu değerlendirme sonucunda belediyelerin yıllar içinde Türkiye sıralamaları elde edilmiştir. Bu çalışmada da tek boyutlu kümeleme analizi ile belediyelerin sıralanmasında kullanılan değerler ile gruplandırılmıştır. En uygun küme sayısı, Elbow yöntemi ile ' 5 ' olarak bulunmuştur. En iyi kümenin 1 en kötü kümenin 5 olduğu durumda kümeleme analizi performans ölçüm aracı olarak kullanılmıştır. Çalışmada ele alınan yıllarda en iyi kümede İstanbul, Ankara, Bursa ve Eskişehir şehirleri; en kötü kümede ise Ardahan, Hakkâri, Muş şehirleri bulunmaktadır. Bu çalışmada kümeleme analizi gruplandırmanın yanı sıra performans ölçüm aracı olarak kullanılmıştır. Çalışmada illerin yanı sıra coğrafi bölgelerin de kümeleme analizi ile performansı değerlendirilmiştir. Marmara bölgesi en başarılı bölge olarak ortaya çıkmıştır.

İllerin yıllar içinde çevrecilik performansı, belediyelerin çevreci hizmetlerinin kalitesini de gösterdiği söylenebilir. Yıllar içinde değişen yönetimlerin veya belediye başkanlarının etkisine bakılarak yerel yönetimde belediye ve belediye başkanları performanslarına siyasi bir yorum getirilebilir. Büyükşehir belediyelerinin diğer şehir belediyelerine göre performansları incelenerek, büyükşehir olmanın etkisi ölçülebilir. Siyasi parti değişimin belediyeler üzerindeki etkisini ölçmek için yıllar içindeki parti değişimlerine bakılabilir. Belediye başkanın değişmesine göre performansına bakarak belediye başkanları hakkında fikir sahibi olunabilir. Bu çalışmada uzmanlar tarafından belirlenen kriterlerin ağılıkları, aynı kriterleri kullanacak benzer çalışmalarda kullanılabilir. 


\section{Eskişehir Osmangazi Üniversitesi iiBF Dergisi}

\section{Kaynaklar}

Bholowalia, Purnima; Kumar, Arvind (2014) “EBK-means: A Clustering Technique Based on Elbow Method and K-Means in WSN", International Journal of Computer Applications, 105(9), 17-24.

Bostancı, Bülent (2016), “Belediye Hizmet Kalitesinin Bulanık AHS Ağırlıkları ile Nominal Değerlemesi”, Electronic Journal of Map Technologies, 8(2), 110-130.

Cieszynska, Monika; Wesolowski, Marek; Bartoszewicz, Maria; Michalska, Malgorzata; Nowacki, Jacek (2012), “Application of Physicochemical Data for Water-Quality Assessment of Watercourses in the Gdansk Municipality (South Baltic coast)", Environmental Monitoring and Assessment, 184(4), 2017-2029.

Güner, Samet (2017), "Toplu Ulaşım Sistemlerinde Operasyonel Etkinlik ve Hizmet Kalitesi Analizi”, Journal of Transportation and Logistics, 2(2), 33-48.

Güven, Ahmet; Şimşek, Gül (2018), “Yerel Yönetimlerin Sosyo Ekonomik Gelişimi ve Tanıtımı Açısından Film Platolarının Önemi: Midwood Örneği", Journal of Turkish Court of Accounts/Sayistay Dergisi, (108).

Hamurcu, Mustafa; Eren, Tamer (2015), “Ankara Büyükşehir Belediyesi'nde Çok Ölçütlü Karar Verme Yöntemi ile Monoray Güzergâh Seçimi”, Transist, 8, 410-419.

Huang, Xiaohui; Ye, Yunming; Guo, Huifeng; Cai, Yi; Zhang, Haijun; Li, Yan (2014), “DSK-means: a New Kmeans-Type Approach to Discriminative Subspace Clustering", Knowledge-Based Systems, 70, 293-300.

Kodinarıya, Trupti M.; Makwana, Prashant R (2013), "Review on determining number of Cluster in K-Means Clustering", International Journal, 1(6), 90-95.

Mustafa, Mustafa A.; Al-Bahar, Jamal F. (1991), "Project Risk Assessment Using the Analytic Hierarchy Process", IEEE Transactions on Engineering Management, 38(1), 46-52.

Nydıck, Robert L.; Hill, Ronald P. (1992), “Using the Analytic Hierarchy Process to Structure the Supplier Selection Procedure", International Journal of Purchasing and Materials Management, 28(2), 31-36.

Olson, David L.; Delen, Dursun (2008), Advanced Data Mining Techniques. Springer Science \& Business Media.

Ramanathan, R. (2001), "A Note on the Use of The Analytic Hierarchy Process for Environmental Impact Assessment", Journal of Environmental Management, 63(1), 27-35.

Ray, Siddheswar; Turi, Rose H. (1999, December), “Determination of Number of Clusters in K-Means Clustering and Application in Colour Image Segmentation". In Proceedings of The 4th International Conference on Advances in Pattern Recognition and Digital Techniques, 137-143.

Saaty, Thomas L. (2008), "Decision Making with the Analytic Hierarchy Process". International Journal of Services Sciences, 1(1), 83-98.

Syakur, M. A.; Khotimah, B. K.; Rochman, E. M. S.; Satoto, B. D. (2018, April), “Integration K-Means Clustering Method and Elbow Method for Identification of the Best Customer Profile Cluster", In IOP Conference Series: Materials Science and Engineering, IOP Publishing, 336(1), 1-6.

Tucker, Conrad S.; Kim, Harrison. M.; Barker, Douglas E.; Zhang, Yuanhui (2010), “A ReliefF Attribute Weighting and Xmeans Clustering Methodology for Top-Down Product Family Optimization”, Engineering Optimization, 42(7), 593616.

Türkiye İstatistik Kurumu (TÜiK), https://biruni.tuik.gov.tr/medas/?locale=tr (Erişim Tarihi: 03.01.2019)

Vaidya, Omkarprasad S.; Kumar, Sushil (2006), "Analytic Hierarchy Process: An Overview of Applications", European Journal of Operational Research, 169(1), 1-29.

Witten, Ian H.; Frank, Eibe; Hall, Mark A. (2016), Data Mining: Practical Machine Learning Tools and Techniques, Morgan Kaufmann.

Zengin, Eyüp (2009), "Yerel Yönetimler ve Çevre", Journal of Qafqaz University, 26, 116-123.

Zha, Hongyuan; He, Xiaofeng; Ding, Chris; Gu, Ming; Simon, Horst (2002), "Spectral Relaxation for K-Means Clustering", In Advances in Neural Information Processing Systems, 1057-1064.

Zülfikar, Haluk; Beken, Nalan (2014), "Belediyeler ve Çevre Hizmetleri Üzerine Analitik Bir Bakış: Türkiye Örneği". Sosyal Siyaset Konferansları Dergisi, (66-67), 75-100. 


\section{Extended Summary}

\section{Using K-means Cluster Analysis for Assessment of Environmental Services of Municipalities}

Municipalities have become important and indispensable units of public administration in all countries. While these units provide services such as cleaning, sewerage, garbage collection and transportation to meet the daily needs of the public, they also carry out many important tasks such as education, health and infrastructure, which are of great importance for the country's development. In addition to the increasing service demands of the urban population as a result of rapid urbanization, population growth and migration, new service demands of the population, which emerged through technological development, are also met by local governments. The idea of the provision of services by local and closest administrative units around the world increases the importance of local administrations (municipalities).

In this study, although municipalities have many duties and responsibilities, 81 provinces municipalities in Turkey is evaluated in terms of environmental services. In this study, Turkey Statistical Institute (TSI), published by the related municipal services between the years 2001-2016 statistics were used.

In order to measure the environmental services of municipalities; waste disposal rate, proportion of municipal population served with waste service, proportion of municipal population served by waste water treatment plant, proportion of municipal population served by sewerage network, proportion of municipal population served by drinking water treatment plant, service by drinking and utility water network the proportion of the given municipal population was determined as criteria.

Analytical Hierarchy Process (AHP), which is one of the Multi Criteria Decision Making (CCP) methods, was used to determine the weights of the criteria The result of AHP shows that, the proportion of municipal population served by drinking water treatment plant has the highest weight, while the proportion of municipal population served by sewerage network has the lowest weight. Total environmental errors were calculated by multiplying the weights of all criteria and the values of the related years. Decreasing the error of the year comparing to previous year means that; the municipality has achieved better environmental values than the previous year.

According to calculated total environmental error; Diyarbakır, Adana, Kilis, Rize and Bolu provinces were determined to be the top 5 provinces showing the most development from year 2001 to 2016 . When the rankings in all years are evaluated together, in terms of environmental performance; Istanbul, Ankara, Kocaeli, Yalova, Eskisehir are seen as the top five provinces. Hakkâri, Mus, Ardahan, Şırnak and Mardin are the last 5 provinces. According to calculated total environmental error of all Turkey municipalities, there is a decrease in the relevant years.

In this study, clustering analysis was also used to evaluate the environmental errors of municipalities. With clustering analysis, the data is divided into similar groups. Total environmental errors, which consist of similar environmental data of each province, were clustered with one-dimensional clustering analysis for each year. The K-means algorithm, which is frequently used in clustering problems, is used in this study. Elbow method was used to determine the most appropriate ' $\mathrm{k}$ ' number in the $\mathrm{K}$-means cluster analysis. It was determined that total environmental errors should be divided into 5 clusters in each year. Clustering analysis identified clusters including provinces in the years studied. We set the ranking from one to five, 1 best cluster, 5 worst cluster. According to the clustering analysis, when the clusters including the provinces are examined, it can be observed that the provinces have moved to a better cluster or a lower cluster. Istanbul, Ankara, Bursa and Eskisehir have managed to be in the first cluster each year. Şırnak, Mardin, Giresun, Bitlis, Kahramanmaraş, Hatay, Bingöl and Ağrı were also sorted to be unsuccessful in terms of cluster analysis. When the geographical regions are analyzed, it is seen that Marmara region is the most successful region in cluster analysis. Marmara region was followed by İç Anadolu, Ege, Karadeniz, Akdeniz, Güney Anadolu and Doğu Anadolu regions.

In this study, weighted environmental errors were evaluated together with six criteria and multidimensional clustering analysis was performed. Clusters including provinces were also determined by multidimensional analysis. It was observed that the analysis yielded similar results with the one-dimensional clustering analysis. The similarity was revealed by correlation results. The average of the correlations between two clustering analyzes was found $(0,87)$. Thus, it can be said that there is a strong positive relationship between the two analyzes.

As a result, environmental services of municipalities are discussed. Six criteria have been identified to measure environmental services. With municipal statistics and AHP weights, environmentalism services in Turkey's 81 provinces are calculated. These measurements were obtained over the years as a result of municipal rankings in Turkey. In this study, the values used in the ranking of municipalities are grouped with one-dimensional clustering analysis. The best number of clusters was found to be 5 by Elbow method. Cluster analysis was used as a performance measurement tool when the best cluster named " 1 " and the worst cluster named " 5 ". In this study, Istanbul, Ankara, Bursa and Eskisehir were the best cities in clustering analysis in the years discussed; Ardahan, Hakkâri and Muş are the worst cities in the 


\section{Eskişehir Osmangazi Üniversitesi iiBF Dergisi}

worst clusters. In the study, the performance of geographic regions was also evaluated by cluster analysis. Marmara region has emerged as the most successful region. As a result of this study, municipalities which has poor performance can take consideration in to the criteria so can improve their environmental services. Thus, managers who increase this environmental service may be more advantageous in future elections.

In the future it may be improved by adding different criteria in addition to this study. Different weighting methods can be used other than AHP. With the help of the results obtained, the performance of the provinces can be evaluated and the results can be compared. With the findings obtained, the superiority and weaknesses of the provinces against each other can be examined and decisions can be taken by the municipal administration. At the same time, political party leaders can make decisions about mayors and their administrations based on environmentalism measures. 